\title{
The ammonite succession in the Middle Jurassic of East Greenland
}

\author{
JOHN H. CALLOMON
}

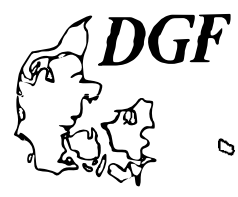

Callomon, J. H.: The ammonite succession in the Middle Jurassic of East Greenland. Bull. geol. Soc. Denmark, Vol. 40, pp. 83-113. Copenhagen, June 3th, 1993. https://doi.org/10.37570/bgsd-1994-40-03

\begin{abstract}
The ammonite sequence in the Middle Jurassic of central East Greenland is the most complete and detailed known in the Arctic so far, and has become a standard of reference for the whole of the Boreal Faunal Province. It is made up of some 37 distinguishable assemblages that characterize a time-ordered succession of discrete faunal horizons. This succession has been pieced together from over 80 recorded sections in Jameson Land lying between Scoresby Sund and Kong Oscars Fjord (70-72 $\mathrm{N})$. It forms the biostratigraphic basis for the regional chronostratigraphy.

The faunal assemblages are listed and described by reference to published illustrations in the literature. Faunas 1-23 are of pre-Callovian age and have no elements in common with their contemporaries in the classical regions of Europe. They still cannot be correlated with the European standard pre-Callovian chronozonations. Most of them must be of Bathonian age, although the earliest of them could well be, and probably are, even still Upper Bajocian. The Bathonian-Callovian boundary most probably lies some-where in faunas 24-26, which closely resemble those of the keppleri horizon at the base of the Callovian. Faunas 2735 span the rest of the Lower Callovian, while faunas 36 and 37 are the only evidence of Middle and Upper Callovian. The ammonites from Jameson Land previously described by Spath (1932) are revised and assigned to their correct horizons. Of 11 new species, only one is formally named: Kepplerites vardekloeftensis sp. nov., of latest Bathonian age.
\end{abstract}

John H. Callomon, Universitý College London, 20 Gordon Street, London WCIH OAJ, U.K. September $28 t h, 1992$.

\section{Introduction}

The history of our knowledge of the Middle Jurassic of East Greenland has been told many times. The first ammonites to be described, by Madsen (1904), were brought back from Jameson Land by the Danish expedition led by Amdrup and Harts in 1900. This expedition, like others, had been one of general exploration. The systematic study of the geology of East Greenland began with the many expeditions led by Lauge Koch in the years 1926-58. The widespread presence of richly fossiliferous Middle Jurassic sediments became apparent already during the first of these, 1926-7, when large collections of ammonites were made by Rosenkrantz and Tom Harris in the region of Jameson Land west of Hurry Inlet. These were described in a classical monograph by Spath (1932) which in many ways remains the standard work of reference even today, at least as concerns the description of species. Its main shortcoming was a lack of detailed stratigraphy, so that the relative successions of forms had in part to be inferred and the type horizons of most of them were not precisely known. A further good collection from Jameson Land was made in 1933 by Aldinger (1935), who produced some excellent maps and recorded the first usable sections. His collection was also submitted to Spath at the British Museum, but it was never described. After the war, exploration was resumed north of Kong Oscars Fjord $\left(72^{\circ} \mathrm{N}\right)$, into Traill $\emptyset$, but although the Middle Jurassic there is thick and extensive, ammonites are scarce and scattered. The state of knowledge at the time was comprehensively reviewed by Donovan (1957).

A new phase in the study of the Middle Jurassic started with Koch's last two expeditions in 1957 and 1958. It was prompted by a re-examination of the ammonite faunas in the light of what had been learned in the meantime about those of the Middle Jurassic more generally. Some of the forms from East Greenland were clearly congeneric with European ones. They are members of the families Cardioceratidae and Kosmoceratidae, which make a sudden appearance in Europe somewhere in the lower part of the Callovian Stage and then range upwards. They were however not conspecific. Others were quite different, totally unknown in Europe but 


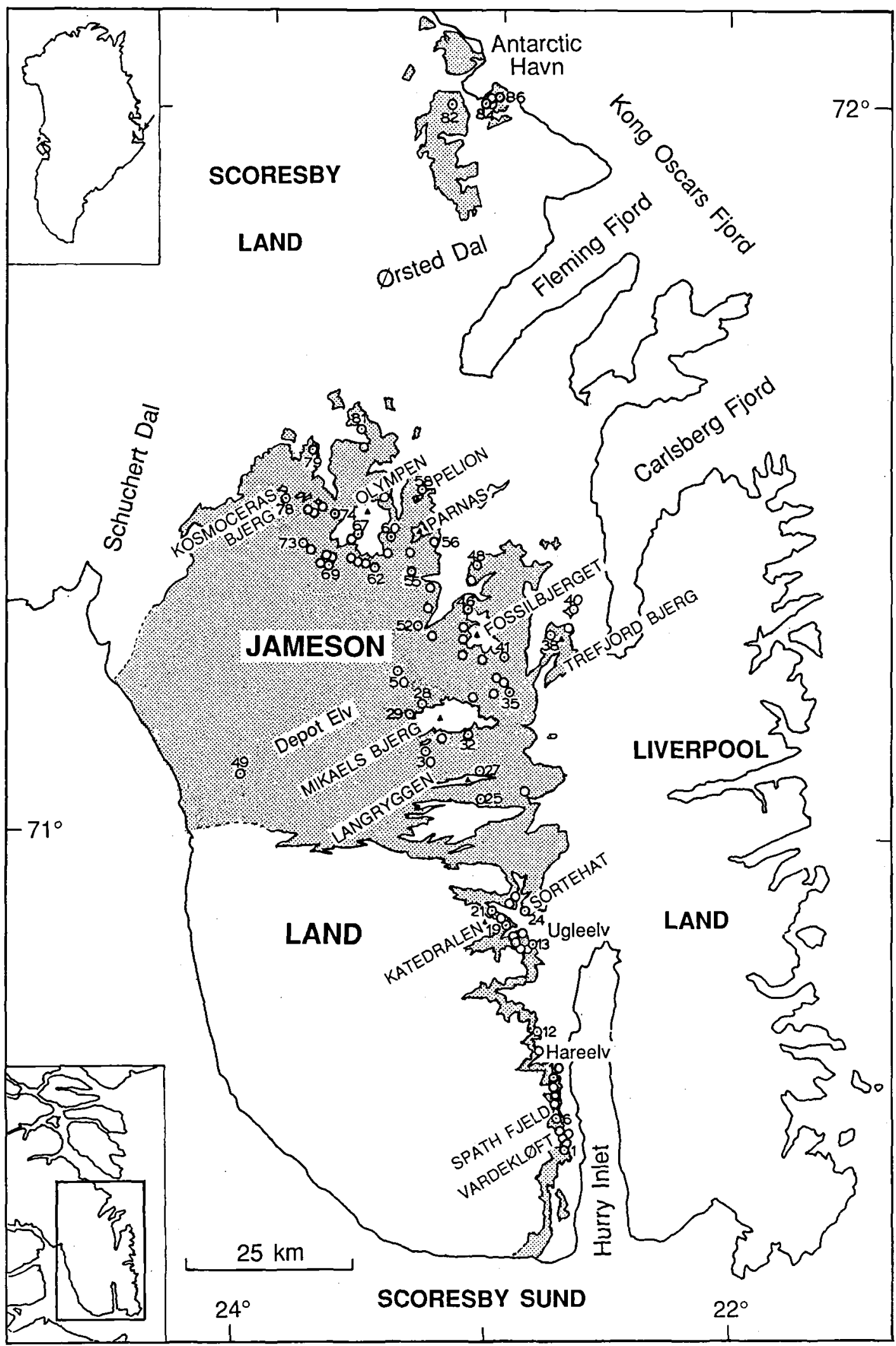


previously recorded from elsewhere in the Arctic, as in the Petshora (Keyserling 1846), the islands of Franz Josef Land (Newton 1897, Whitfield 1907) and Novaya Zemlya (Salfeld \& Frebold 1924). The evidence from East Greenland suggested a succession of four ammonite associations of which only the highest closely resembled European Callovian forms. But the three below it resembled even less anything known elsewhere from the underlying Bathonian Stage. The most cautious approach, therefore, was to assume that the morphological differences between the Greenland and European members of the Cardioceratidae and Kosmoceratidae might have represented merely biogeographic differences, their ages being about the same, late Lower Callovian; and that the underlying assemblages were only a little older, quite possibly also already early Lower Callovian or perhaps still just late Upper Bathonian. Such an interpretation seemed to fit well a more general picture expounded by Arkell in his influential book (1956), of the Bathonian as a time of world-wide marine regression leaving no sediments - or, at least, no ammonites like those of the Bathonian of Europe recently monographed by him. Attempts to date these Arctic faunas more closely clearly could make no progress without new evidence.

Efforts were therefore concentrated in 1957-8 on the ammonite biostratigraphy of southern $\mathrm{Ja}$ meson Land, making new collections in situ from carefully recorded sections. It became immediately clear that an immensely rich succession of faunas remained to be discovered. After four weeks in the vicinity of Hurry Inlet and Carlsberg Fjord, the number of faunal horizons characterized by clearly distinguishable ammonite assemblages had risen to nine (Callomon 1959). During a private expedition in 1964 led by $\mathrm{R}$. Marris, further faunal horizons were discovered in the area of Olympen by D. Brown and R. C. Whatley, who recorded sections and brought back good collections of ammonites. The resumption of systematic mapping of central East Greenland by the Greenland Geological Survey (GGU) in 1968 provided access to the remoter interior of Jameson Land where yet further localities were discovered (Birkelund, Håkansson \& Surlyk 1971). Subsequent expeditions in 1970, 1971 and 1974 completed the field-work and led to the publication by GGU of geological maps at $1: 100,000$ of the whole area with Mesozoic sediments lying between Kong Oscars Fjord and Scoresby Sund $\left(70-72^{\circ} \mathrm{N}\right)$.

In all, over 80 sections yielding Middle Jurassic ammonites have been recorded and the number of faunal horizons has risen to 37 . Of these, two or three in the middle of the succession yield species of Kepplerites so similar to those that now define the base of the Callovian Stage in Europe (Callomon et al. 1989) that the Bathonian age of the 25 horizons below it can no longer be in doubt. In fact, there is strong evidence that the lowest, the horizon with Cranocephalites borealis, is still early Upper Bajocian in age (Callomon 1984). The ammonite succession of central East Greenland has become the best known and probably the nearest to complete through the Upper Bajocian and Bathonian anywhere in what is now recognized to have been a clearly delimited bioprovincial domain, the Boreal Province, whose ammonites were so strongly endemically restricted that a precise correlation with their temporal equivalents elsewhere in the world remains impossible. Conversely, this succession has been used as a standard of reference for time-correlations within the whole of the Arctic Boreal Province.

Such a reference succession is conveniently cast into the form of a scale of Standard Chronozones (Callomon 1985a). The scale has grown from its early form, which had seven Zones below the Callovian (Callomon 1959, 1972), into the form of to-day, shown in fig. 2, which has nine. Each of these is divisible further into Subzones, but this must await a full taxonomic evaluation and description of the ammonite faunas and their correlations with those elsewhere, a task beyond the present scope. Most of the ammonite species have however already been described in some form somewhere or other, notably in Spath's monograph. The purpose of the present account is therefore to present a compilation of the ammonite succession that should be more widely usable by reference to descriptions

Fig. I. Outcrop of Middle Jurassic sediments in Jameson and Scoresby Lands, central East Greenland, with place-names and locations of recorded sections, numbered 1-86 from $S$ to $N$. 


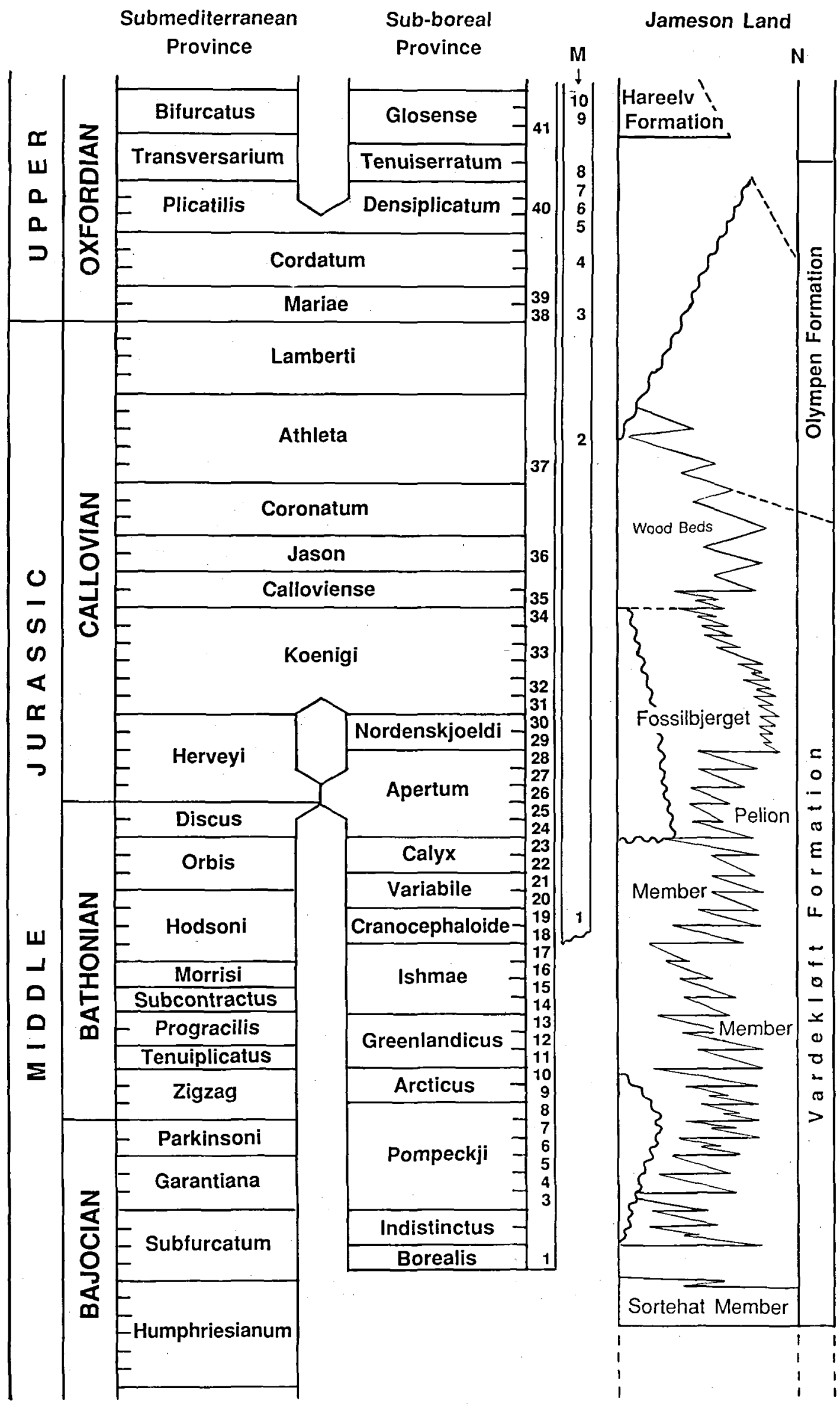


already in the literature, modeled on a similar compilation of the 46 ammonite horizons recognized in the Upper Jurassic of Milne Land (Callomon \& Birkelund 1980, 1982, Birkelund, Callomon \& Fürsich 1984).

\section{Lithostratigraphy}

The outcrop of Middle Jurassic rocks between Scoresby Sund and Kong Oscars Fjord is shown in fig. 1. The positions of the sections are indicated, as are the names of some important localities.

The lithostratigraphy has been described by Surlyk et al., who illustrated some typical and important sections (1973, figs 14-23). The Middle Jurassic is represented by the Vardekløft Formation, which has been subdivided into three Members (see fig. 2). Of these the lowest, the Sortehat Member, lies disconformably on the Ostreaelv Member of the Niells Klinter Formation, of Lower Toarcian age. The Sortehat Member consists mainly of black shales with sideritic concretions and extends with little change from southern Jameson Land northwards as far as Kong Oscars Fjord and perhaps into Traill $\emptyset$. Its thickness varies between $60 \mathrm{~m}$ in the south and $120 \mathrm{~m}$ in the north. The only macrofossils are belemnites and rare oysters. Its age is not closely documented. Its upper boundary is however conformable with, and to some degree gradational into, the overlying Pelion Member whose base is characterized by Cranocephalites borealis. It is assumed therefore to be only moderately older. The best guess is Bajocian, the whole of the Aalenian and Upper Toarcian being lost in the nonsequence.

The Pelion Member attests to the onset of vigorous blockfaulting, pitching northwards. Its thickness in southern Hurrv Inlet is only $5 \mathrm{~m}$, but it increases rapidly northwards, reaching $150 \mathrm{~m}$ at the head of Hurry Inlet (Katedralen), $300 \mathrm{~m}$ at
Pelion and $550 \mathrm{~m}$ at Antarctic Havn on the southern shore of Kong Oscars Fjord. In Traill $\emptyset$ it is at least $700 \mathrm{~m}$ thick. It consists of siliclastic arenites, locally with some cobble conglomerates. Its upper boundary is gradational and diachronic, so that in the north it has laterally replaced the whole of the Fossilbjerget Member. Sedimentation was highly episodic and discontinuous, crossbedded forsets attaining thicknesses of up to 30 $\mathrm{m}$. There are rich assemblages of trace-fossils, which have been used as bathymetric indicators in an evolutionary basin analysis by Heinberg and Birkelund (1984).

The Fossilbjerget Member consists mainly of silty, micaceous shales, locally indurated into concretions of all sizes, with subordinate thin shaly fine-grained sandstones. Thicknesses range from $120 \mathrm{~m}$ in Hurry Inlet to $100 \mathrm{~m}$ at Pelion, where sandstones begin to be important, taking over completely at Antarctic Havn. The upper 20 $m$ in southern Jameson Land are marked by an abundance of fossil wood in the form of silicified logs (the Wood Beds). Despite a rather monotonous aspect, detailed sedimentology and fossil evidence show quite clearly that sedimentation was here also highly discontinous. There are marked cyclic sequences: barren fine-grained shales passing upwards into indurated shales or coarser doggery sandstone and terminating in thin, red-weathering glauconitic conretionary horizons with abundant fossils which are preserved as phosphatized casts or as nuclei of phosphatic concretions. Each cycle represents typically the interval between two separate ammonite faunal horizons, i.e. a significant fraction of an ammonite Zone, and may span 1-20 m of sediment. Any sedimentary structures there may have been have usually been obliterated by bioturbation, so that no primary sedimentological evidence remains to indicate the original rate of sedimentation and, conversely, the duration of non-sequences; but of the importance of such gaps there can be no doubt.

The upper boundary of the Fossilbjerget Mem-

Fig. 2. Summary of litho- and standard chronostratigraphies of the Middle and early Upper Jurassic sediments in Jameson Land. The chronostratigraphic units are standard ammonite Zones in the relevant biogeographic provinces. The smallest equispaced units defining the scales in the Submediterranean column are standard Subzones (not explicitly written out as such) or, where these are widely further subdivisible, extensively recognizable ammonite horizons. The appearance of parallel provincial standard zonal units opposite each other at the same height is a schematic device that does not imply time-correlation. The 41 ammonite faunal horizons recognized in East Greenland are numbered as in the text and are shown at the side of the Sub-boreal column. The numbers 1-10 in the column under " $\mathrm{M}$ " refer to the faunal horizons recognized at Kap Leslie in Milne Land. 


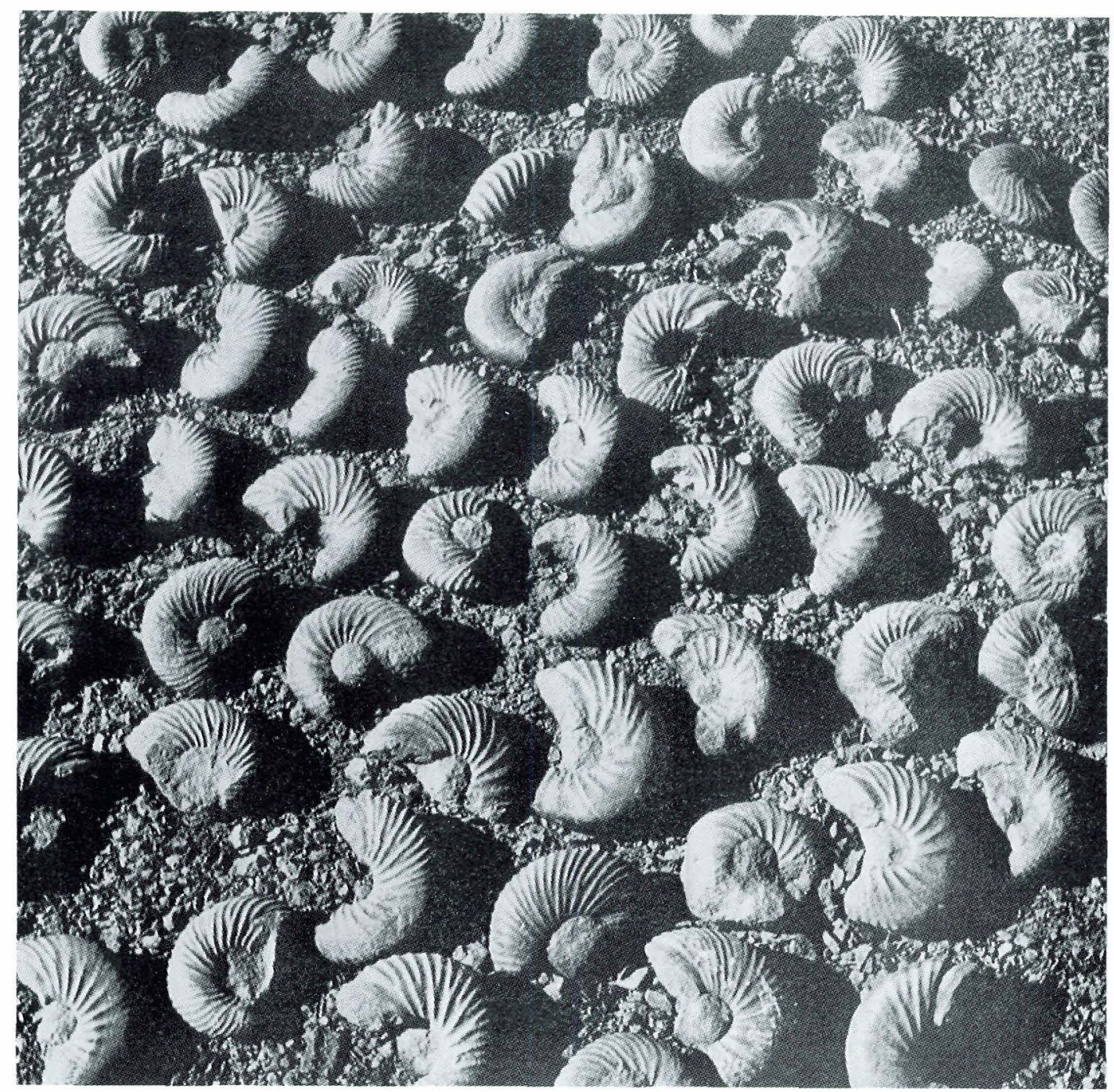

Fig. 3. Part of a collection of Arcticoceras cranocephaloide Callomon \& Birkelund, topotypes, gathered from a layer of slightly phosphatic concretions on the southern slopes of Fossilbjerget between sections 42 and 43 by Tove Birkelund and Claus Heinberg in 1974. Note that the specimens are all adult and macroconchs, which dominate over microconchs in a ratio of at least 50:1. (From Birkelund \& Perch-Nielsen 1976).

ber is variable, reflecting a change in tectonic regime in the Upper Oxfordian. In southern Jameson Land it is sharply terminated somewhere in the Upper Callovian by an erosional non-sequence, overlain by late Middle or early Upper Oxfordian Hareelv Formation. In central Jameson Land there is a gradational transition in Lower Oxfordian to a renewed succession of clean, fine to medium-grained silicarenites, the Olympen Formation. In northern Jameson Land the transition has descended into the Upper Callovian, which is there already included in the
Olympen Formation. In Traill $\varnothing$, no boundary can any longer be drawn between Pelion Member and Olympen Formation, and fossils have become too rare to be usable as time-controls.

\section{Biostratigraphy}

The biostratigraphy of the Middle Jurassic is dominated by that of the ammonites. Their occurrences epitomize some very general features 
of this group of fossils, pointing to a strong ecological control of their immediately premortal distributions (Callomon 1985b). The shells are concentrated in sharply defined layers, usually separated by thicknesses of sediment in which they are absent or best very sparsely scattered. Often the fossiliferous layers coincide with tops of sedimentary cycles described above, enriched in glauconite, which suggests accumulation at clastic omission-surfaces or lag-deposits - "condensed deposits"; but there are no signs of reworking, abrasion, boring or epifaunal encrustation usually symptomatic of such deposits. There is also almost no other benthos, such as bivalves. Sometimes, in sandstones, the surrounding sediments still retain some sedimentary structures such as cross-bedding. Elsewhere the shells of sphaeroconic groups such as Cadoceras may be preserved end-on, at the angles at which they came to rest on the sea-floor. Most of the shells are complete and unbroken, although they may have become diagenetically deformed. At some horizons, the abundance of fossils can be enormous. One example was illustrated already by Rosenkrantz (1929, p. 146), whose legend to a photograph taken in central Jameson Land (fig. 44) states: "In the foreground thousands of ammonites lie spread over the ground". In the the fine-grained sediments of the Fossilbjerget Member, these ammonite-beds can sometimes be followed for distances up to $20 \mathrm{~km}$ across country, although the richness of the fossil-content may vary much more rapidly and fade to nothing. In the coarser sandstones of the Pelion Member, in which the sediments are built up of sharplybounded beds of variable lithologies, showing signs of rapid deposition, the distribution of ammonites is similarly spasmodic. A thick and monotonous sequence of sandstones marked only by occasional levels of trace-fossils is suddenly punctuated by a bed, usually less than a metre thick, in which ammonites are again abundant. Beds such as these are usually impersistent and lenticular, extending for no more than a few hundred metres. The taphonomic evidence suggests, therefore, a distribution determined not so much by random accidents of preservation as by relatively infrequent and short-lived periods of regional habitation by ammonites.

Stronger evidence in support of such an interpretation comes from the compositions of the assemblages themselves. They have very low diversities. Almost all the faunas fall into only two families. Those occurring in the lower and middle parts of the Vardekløft Formation belong exclusively to the Cardioceratidae, which continue upwards and are joined in the upper parts of the formation by Kosmoceratidae. With only few exceptions, the assemblages are at every level monospecific within each family. These features, sometimes cited as characteristic of so-called "impoverished faunas", are typical of habitats at high latitudes and call for no special comment. They can provide ideal examples for evolutionary studies and the Cardioceratidae of East Greenland constitute a substantial segment of what must now be one of the longest and most closely-documented lineages we know (Callomon 1985b). More striking is the make-up of the species themselves.

The assemblages at almost every faunal horizon consist nearly exclusively of mature adults of only one sex: the macroconchs, presumed to have been females. An example from Fossilbjerget in Jameson Land shown by Birkelund and PerchNielsen (1976) is reproduced here in fig. 3. Demonstrably immature individuals cannot number more than a percent or two of the total; and the sex-ratio is rarely less than $10: 1$, and can be higher than 100:1, in favour of the macroconchs. In contrast, there occur, in the otherwise unfossiliferous beds between ammonite horizons in the Fossilbjerget Member of southern Jameson Land, very rare concretions packed with small ammonites that are again complete but consist entirely of juveniles. Finally, the assemblages in successive ammonite-beds are almost invariably distinguishable in overall morphology, showing that detectable evolutionary changes have taken place. Rough estimates of average time-interval indicate periods of the order of 100,000 years. Yet within each assemblage the morphological variation, although considerable, is very homogeneous in a way again indicating close contemporaneity. An interpretation of these distributions (Callomon 1985b) is based on a mode of life resembling that of many nektonic cephalopods to-day. During their well-defined life cycle they migrated gregariously, probably spending their growing stages nektonically on the high seas and returning to their benthic spawning-grounds only when fully grown, sexually mature and segre- 


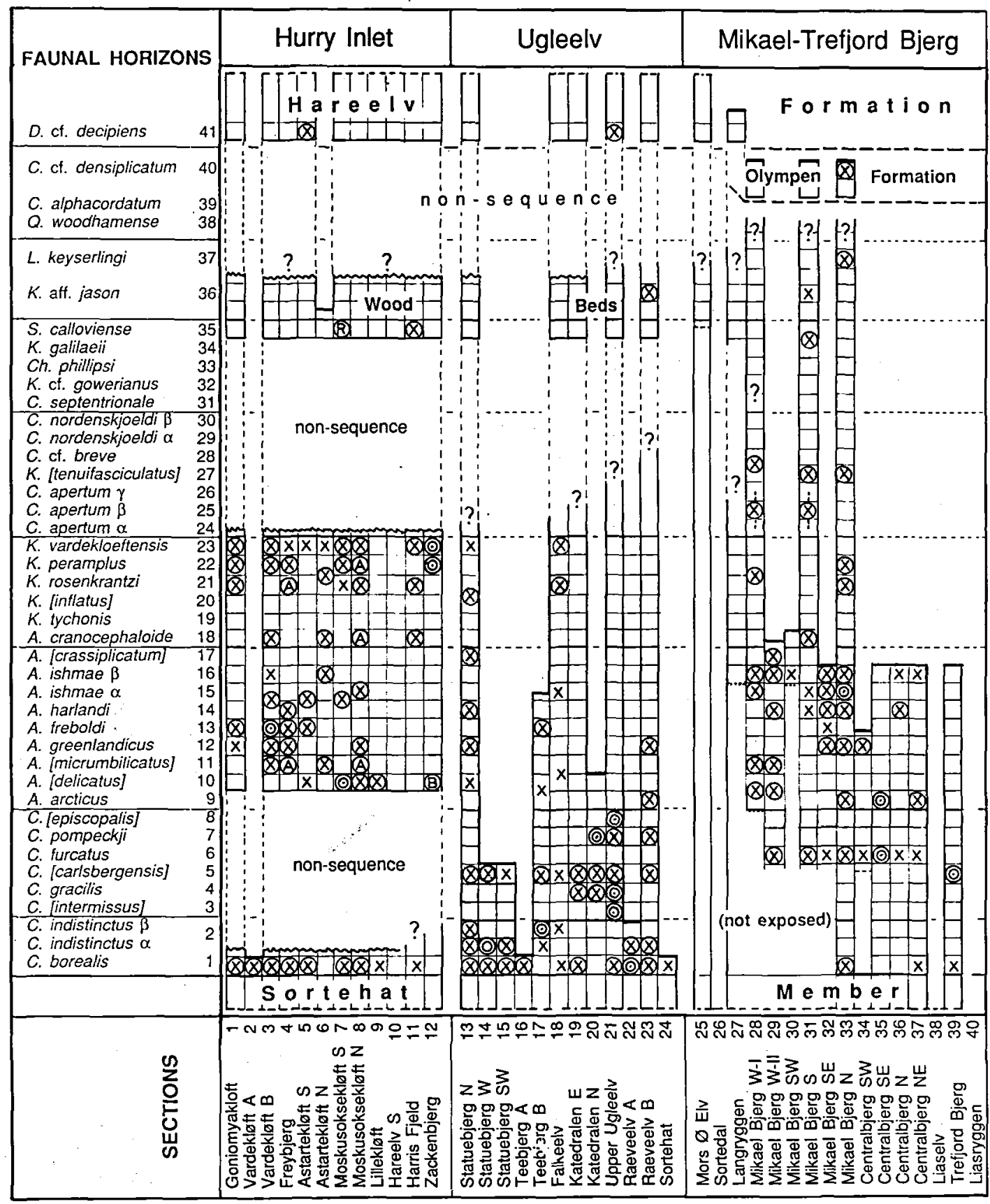

gated, to breed and, in the case of the females, to spawn and then to die. Hence we find their shells at the restricted localities at which the animals made their only relatively brief contact with the marine substrate, their spawning and dyingground Hence the resolution of an apparent paradox, of a group of organisms inhabiting, and evolving in, a wide biogeographic region probably continuously for millions of years, yet leaving a fossil record that is highly spasmodic and strongly polarized in the selection of only one ontogenetic stage.

Such, then, is the nature of the ammonite record in East Greenland: a highly discontinuous, 


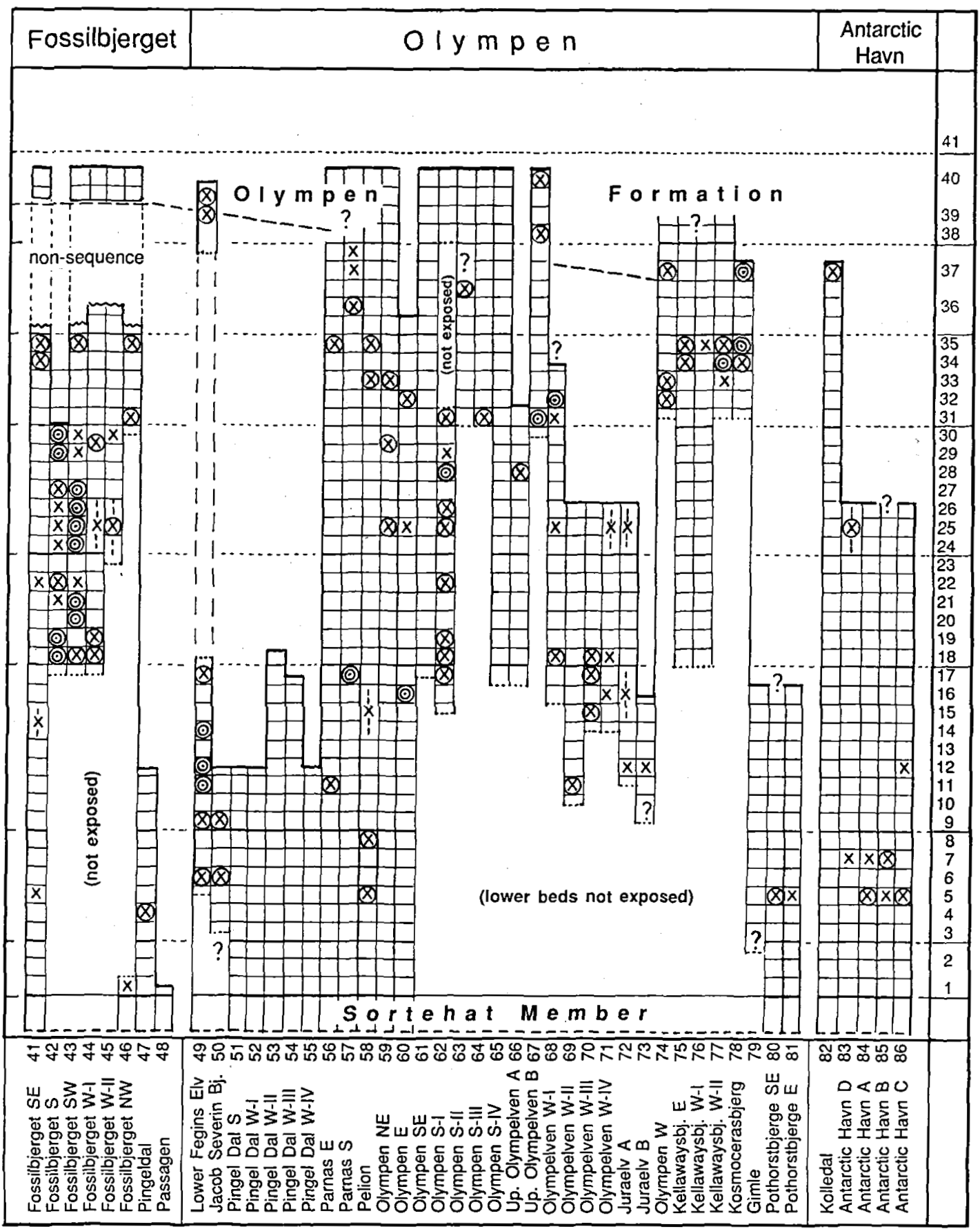

Fig. 4. Synopsis of recorded sections 1-86 in Jameson and Scoresby Lands, central East Greenland, indicating in which the 41 faunal horizons have been recognized. Crosses: field identifications; crosses and circles: collections made; double circles: type-localities of faunal horizons and their characteristic assemblages (not necessarily those of the index-species themselves). Some sections are indicated even through no ammonites have been recorded from them. Such sections can nevertheless be of great value for local, short-distance correlations by lithology. Collections taken into consideration include those made by Rosenkrantz or Harris in 1926-27, described by Spath (1932: see Table I herein); additional material collected by Rosenkrantz in 1934, marked "R"; by Bütler in 1934 ("B"); and by Aldinger in 1933 ("A"). Rosenkrantz's sections "Vardekløft localities A-C" (in Spath 1932) are the present sections 2 and 3 ; his locality " $D$ ". was at Goniomyakløft, section 1. Aldinger's collections could be tied into his published sections (Aldinger 1935), which were also subsequently re-recorded and recollected. His "Signalalp = Freyberg Fjeld" is section 4; "Signalalp $2 \mathrm{~A}=$ Spath Fjeld", section 7; and "Signalalp $5 \mathrm{~A}=$ Brinkmann Fjeld", section 8 . There are additional voluminous collections made by Stauber in 1938, in many cases of excellent and important material, but the indications of locality are at best vague and there is no stratigraphical information. Section 49 is a composite record of numerous short part-sections exposed in shallow river-banks around the lower reaches of Fegins, Depot and Draba Siberica Elven. 
Table I. Key to horizons and localities of ammonites from Jameson Land, East Greenland, figured by Spath (1932).

\begin{tabular}{|c|c|c|c|}
\hline $\begin{array}{l}\text { Plate \& } \\
\text { figure }\end{array}$ & $\begin{array}{l}\text { Faunal } \\
\text { horizon }\end{array}$ & $\begin{array}{l}\text { Nearest } \\
\text { section }\end{array}$ & Identification \\
\hline $1-1$ & $1 c$ & $20-21$ & Cranocephalites maculatus Spath [M] (HT) [= C. gracilis Spath pars?] \\
\hline-2 & 7 & $20-21$ & C. pompeckji (Madsen) [M] \\
\hline-3 & 7 & $20-21$ & C. pompeckji (Madsen) [M] \\
\hline-4 & 7 & $20-21$ & C. pompeckji (Madsen) [M] [=C. vulgaris Spath (HT)] \\
\hline $2-1$ & 7 & $20-21$ & C. pompeckji (Madsen) [M] \\
\hline-3 & 4 or 7 & $19-21$ & C. cf. or aff. pompeckji (Madsen) [M] \\
\hline-4 & 7 & $19-21$ & C. cf. pompeckji (Madsen) [M] \\
\hline-6 & $4 b$ & $19-21$ & C. gracilis Spath [M] var. ornatus (type) \\
\hline $3-1$ & $4 b$ & $19-21$ & C. gracilis Spath [M] (HT) \\
\hline-2 & 9 & $35-37$ & Arctocephalites cf. arcticus (Newton) \\
\hline$-\overline{3}$ & 6 & $35-37$ & Cranocephalites furcatus Spath [m]? \\
\hline-4 & 7 & $20-21$ & C. pompeckji (Madsen) [M] (juvenile)? \\
\hline-5 & 7 & $20-21$ & C. pompeckji (Madsen), suture-line of 1-4 \\
\hline-6 & 4 & $19-21$ & C. aff. gracilis Spath $[\mathrm{M}]$ (coarse variant) \\
\hline$(-7)$ & (9) & - & (A. arcticus, suture of topotype, 12-2) \\
\hline $4-1$ & 7 & $20-21$ & C. pompeckji (Madsen) [M] \\
\hline-2 & 4 & $19-21$ & C. aff. gracilis Spath $[\mathrm{M}]$ \\
\hline-3 & 7 & $20-21$ & C. pompeckji (Madsen) [M] (typical) \\
\hline $\begin{array}{c}-6 \\
\because \cdots \\
\because\end{array}$ & - & - & $\begin{array}{l}\text { Morrisiceras morrisi (Oppel), suture-line of an English specimen; note the } \\
\text { bifid umbilical lobe diagnostic of the Tethyan family Tulitidae, found } \\
\text { neither in the Cardioceratidae, to which Cranocephalites belongs, nor in } \\
\text { the Macrocephalitinae, a homoemorphic but only distantly related group. }\end{array}$ \\
\hline-7 & 9 & $35-37$ & Arctocephalites arcticus (Madsen) [m] \\
\hline-9 & 6 & $35-37$ & Cranocephalites furcatus Spath [M] \\
\hline-10 & 6 & $35-37$ & C. furcatus Spath [M] \\
\hline $5-1$ & 7 & $20-21$ & C. pompeckji Spath $[\mathrm{M}]$ (compressed variant) \\
\hline-2 & $5 b$ & $84-86$ & C. subbullatus Spath $[\mathrm{M}][=\mathcal{C}$. carlsbergensis sp. nov. MS?] \\
\hline-3 & $5 \mathbf{a}$ & 39 & C. carlsbergensis sp. nov. MS [M] \\
\hline-6 & 6 & $36-37$ & C. furcatus Spath [M] \\
\hline-7 & $5 a$ & 39 & C. carlsbergensis sp. nov. MS [M] \\
\hline $6-1$ & 6 & $35-37$ & C. furcatus Spath [M] (HT) \\
\hline-2 & 6 & $35-37$ & C. furcatus Spath $[\mathrm{M}]$ (small variant) \\
\hline-3 & 9 & $35-37$ & Arctocephalites arcticus (Newton) [M] (fragment) \\
\hline-4 & 9 & $35-37$ & A. arcticus (Newton) [m] \\
\hline-6 & $5 a ?$ & 39 & C. cf. carlsbergensis sp. nov. MS $[\mathrm{M}]$ \\
\hline-7 & $5 b$ & $84-86$ & C. subbullatus Spath [M] (very coarse variant) \\
\hline $7-1$ & $5 a$ & 39 & C. carlsbergensis sp. nov. MS [M] \\
\hline-2 & $5 b$ & $84-86$ & C. subbullatus Spath $[\mathrm{M}]$ \\
\hline-3 & $5 b$ & $84-86$ & C. subbullatus Spath [M] \\
\hline-5 & $5 b$ & $84-86$ & C. subbullatus Spath [M] (HT) \\
\hline-7 & 9 & $35-37$ & Arctocephalites arcticus (Newton) [M] \\
\hline-8 & $5 b$ & $84-86$ & C. subbullatus Spath [M] \\
\hline $8-1$ & 7 & -21 & C. pompeckhji (MAdsen) [M] (typical) \\
\hline-2 & $?$ & $35-37$ & Arctocephalites cf. or aff. arcticus (Newton) \\
\hline-3 & $\dot{9}$ & $35-37$ & $\begin{array}{l}\text { A. arcticus (Newton) [M] (fairly inflated variant, intermediate between } \\
\text { arcticus } \text { S.s. and sphaericus) [HT of } A \text {. ornatus Spath] }\end{array}$ \\
\hline-4 & $9 ?$ & 33 & Arctocephalites? sp. indet. (nucleus) \\
\hline-5 & $5 \mathrm{~b}$ & $84-86$ & C. subbullatus Spath $[\mathrm{M}]$ \\
\hline-6 & $15 / 16$ & 33 & Arcticoceras ishmae (Keys.) [M] pars [HT of Cadoceras pseudishmae Spath] \\
\hline $9-1$ & 12 & 19 & Arctocephalites greenlandicus Spath [M] (HT) \\
\hline-2 & - & - & (Pseudocadoceras? sp.; Franz Josef Land) \\
\hline-3 & 9 & $35-37$ & Arctocephalites cf. arcticus (Newton) (nucleus) \\
\hline-4 & $5 ?$ & $35-37$ & Cranocephalites sp. \\
\hline-5 & $4-5 ?$ & $19-21$ & $\begin{array}{l}\text { C. cf. or aff. maculatus Spath or carlsbergensis }[\mathrm{MS}](=\text { C. subextremus } \\
\text { Spath, HT) }\end{array}$ \\
\hline-6 & $9 ?$ & $35-37$ & Arctocephalites sp. indet. $\quad$ (cont.) \\
\hline
\end{tabular}


Table I. (Cont'd).

\begin{tabular}{llll}
\hline $\begin{array}{l}\text { Plate \& } \\
\text { figure }\end{array}$ & $\begin{array}{l}\text { Faunal } \\
\text { horizon }\end{array}$ & $\begin{array}{l}\text { Nearest } \\
\text { section }\end{array}$ & Identification \\
\hline
\end{tabular}

\begin{tabular}{|c|c|c|c|c|}
\hline $10-1$ & 12 & 19 & & A. greenlandicus Spath [M] (HT) (see 9-1) \\
\hline-3 & $7 ?$ & $20-21$ & & C. cf. pompeckji (Madsen), fide Spath (nucleus) \\
\hline-4 & 9 & $35-37$ & & Arctocephalites arcticus (Newton) [M] [HT of $A$. elegans Spath] \\
\hline $11-1$ & 9 & $35-37$ & & A. arcticus (Newton) [M] [HT of $A$. nudus Spath] \\
\hline-2 & 9 & $35-37$ & & A. arcticus (Newton) [m] \\
\hline-3 & $14-16$ & 33 & & Arcticoceras sp. cf. ishmae (Keys.) \\
\hline-4 & - & - & & (Pseudocadoceras sp.; Franz Josef Land) \\
\hline-5 & 9 & $35-37$ & & Arctocephalites arcticus (Newton) [M] pars \\
\hline-6 & 9 & $35-37$ & & A. arcticus (Newton) [M] inflated variant [A. sphaericus Spath pars] \\
\hline-7 & 9 & $35-37$ & & A. cf. arcticus [sphaericus Spath] \\
\hline $12-1$ & 15 & 33 & & Arcticoceras ishmae (Keys.) $\alpha[\mathrm{M}]$ \\
\hline-2 & - & - & & (Arctocephalites arcticus (Newton) [M], topotype, Franz Josef Land) \\
\hline-4 & 9 & $35-37$ & & A. arcticus (Newton) $[\mathrm{M}]$ \\
\hline $13-1$ & 6 & $35-37$ & & Cranocephalites furcatus Spath $[\mathrm{M}]$ \\
\hline-3 & 15 & 33 & & $\begin{array}{l}\text { Arcticoceras ishmae (Keys.) } \alpha[\mathrm{m}][\text { HT of } A \text {. michaelis Spath, allotype of } A \text {. } \\
\text { kochi } \text { Spath] }\end{array}$ \\
\hline$-4,5$ & 15 & 33 & & A. ishmae (Keys.) (see 14-1) \\
\hline-6 & - & - & & (Arctocephalites arcticus pars; Franz Josef Land) \\
\hline 14-1 & 15 & 33 & & Arcticoceras ishmae (Keys.) $\alpha[\mathrm{M}]$ (compressed variant, $A$. kochi Spath) \\
\hline-2 & 15 & 33 & & A. ishmae (Keys.) [M]? \\
\hline-3 & 15 & 33 & & A. ishmae (Keys.) $\alpha[\mathrm{m}]$ \\
\hline-4 & 1 & 33,37 & & Cranocephalites borealis (Spath) [M] (HT) \\
\hline 15-1 & 16 & 33 & & Arcticoceras ishmae (Keys.) [M] [HT of $A$. kochi Spath] \\
\hline-2 & 9 & $35-37$ & & Arctocephalites arcticus (Newton) [M] (nucleus) \\
\hline-3 & $6 ?$ & $35-37$ & & Cranocephalites sp.? [m] \\
\hline-4 & $12 ?$ & $33 \ldots$ & & Arctocephalites cf. greenlandicus \\
\hline-5 & $15-16$ & 33 & & Arcticoceras cf. ishmae \\
\hline-6 & 16 & $33:$ & $\therefore$ & A. ishmae (Keys.) [m] \\
\hline-7 & - & - & $\therefore$ & (A. ishmae (Keys.) [M], Petshora) \\
\hline $16-1$ & 9 & 35-37 & $\cdots$ & Arctocephalites arcticus (Newton) [M] \\
\hline-3 & $10 / 12$ & $2-3$ & & A. cf. crassum (Madsen) [M] \\
\hline-5 & 9 & $35-37$ & & A. arcticus (Newton) $[\mathrm{M}]$ \\
\hline-6 & 23 & 1 & & Cadoceras calyx Spath [M] [C. victor, HT] \\
\hline $17-1$ & 9 & $33-35$ & & $\begin{array}{l}\text { Arcticephalites arcticus (Newton) [M] (the most inflated variant) } \\
\text { [A. sphaericus Spath, HT] }\end{array}$ \\
\hline-5 & 23 & $2-3$ & & Cadoceras cf. calyx Spath $[\mathrm{M}]$ \\
\hline $18-1$ & $12-13$ & 1 & & Arctocephalites cf. freboldi Spath [M] (slightly less strongly ribbed variant) \\
\hline-2 & 13 & $2-3$ & & A. freboldi Spath $[\mathrm{M}](\mathrm{HT})$ \\
\hline $19-1$ & 21 & $10-12$ & & Cadoceras variabile Spath [M] (HT) \\
\hline-2 & 12-13? & $2-3$ & & Arctocephalites? sp. \\
\hline-3 & $23 ?$ & $2-3$ & & Kepplerites cf. vardekloeftensis sp. nov. [M] (septate nucleus) \\
\hline-4 & 9 & $35-37$ & & Arctocephalites cf. arcticus (Newton) (fragment of a [m]?) \\
\hline-5 & $15-16$ & 33 & & $\begin{array}{l}\text { Arcticoceras cf. ishmae (Keys.) [M] (by level and locality; extreme, } \\
\text { spheroconic variant) }\end{array}$ \\
\hline $20-1$ & 23 & 12 & & Cadoceras calyx Spath [M] (HT) (wholly septate, extremely evolute variant) \\
\hline-2 & 23 & $2-3$ & & C. calyx Spath [M] (inner whorls of more typical variant) \\
\hline-5 & $13-14 ?$ & $2-3$ & & Arctocephalites cf. freboldi Spath [M] or Arcticoceras cf. harlandi Rawson \\
\hline $\begin{array}{r}21-1 \\
-5\end{array}$ & 23 & $2-3$ & & Cadoceras calyx Spath $[\mathrm{M}][$ [C. victor; typical variant] \\
\hline-5 & 23 & 1 & & C. calyx Spath [M] (juvenile; compressed, evolute variant) \\
\hline $\begin{array}{r}22-1 \\
-2\end{array}$ & 22 & 1 & & Kepplerites peramplus Spath $[\mathrm{M}]$ \\
\hline-2 & 13-14? & $2-3$ & & Arctocephalites freboldi $[\mathrm{M}]$ or Arcticoceras harlandi $[\mathrm{m}]$ (inflated variant)? \\
\hline
\end{tabular}


Table I. (Cont'd).

\begin{tabular}{|c|c|c|c|}
\hline $\begin{array}{l}\text { Plate \& } \\
\text { figure }\end{array}$ & $\begin{array}{l}\text { Faunal } \\
\text { horizon }\end{array}$ & $\begin{array}{l}\text { Nearest } \\
\text { section }\end{array}$ & Identification \\
\hline $23-1$ & $22 ?$ & $2-3$ & Kepplerites cf. svalbardensis Sok. \& Bodyl. [M] \\
\hline-2 & 23 & $2-3$ & $K$. cf. vardekloeftensis sp. nov. [M] (septate nucleus) \\
\hline-3 & 23 & $2-3$ & K. cf. vardekloeftensis sp. nov. [M] (septate nucleus) \\
\hline-4 & 22 & $2-3$ & $\begin{array}{l}K . \text { cf. peramplus Spath [M] [=K. noblis; or extreme involute variant of } \\
\text { vardekloeftensis?] }\end{array}$ \\
\hline $24-1$ & 22 & 1 & K. peramplus Spath [M] (HT) \\
\hline-2 & $22 / 23$ & $2-3$ & $K$. cf. vardekloeftensis sp. nov. $[\mathrm{m}]$ ? \\
\hline$-\mathbf{3}$ & $23 ?$ & 12 & $K$. pauper (Spath) [m] (HT) \\
\hline-4 & 23 & $2-3$ & $K$. cf. vardekloeftensis (nucleus) \\
\hline-5 & $23 ?$ & $2-3$ & Cadoceras? sp. indet., calyx Spath? \\
\hline-5 & 23 & $2-3$ & Kepplerites vardekloeftensis sp. nov. [M] (paratype) \\
\hline $25-1$ & 23 & $2-3$ & Kepplerites vardekloeftensis sp. nov. [M] (paratype) \\
\hline-2 & 23 & 1 & $K$. vardekloeftensis sp. nov. [M] (HT) \\
\hline $26-1$ & 21 & 1 & $K$. rosenkrantzi Spath $[\mathrm{M}](\mathrm{HT})$ \\
\hline-3 & $23 ?$ & $2-3$ & $K$. cf. vardekloeftensis sp. nov. (cf. 24-4: note barely tabulate venter) \\
\hline-4 & 22 & $2-3$ & $K$. peramplus Spath [M], nucleus \\
\hline-5 & $23 ?$ & 12 & K. pauper (Spath) [m] (HT; cf. 24-3) \\
\hline-6 & 18 & $2-3$ & $K$. sp. nov. G. [stephanoides sp. nov. MS] [M] \\
\hline
\end{tabular}

[M], [m]: macro- or microconch dimorphs, respectively.

[...]: subjective synonyms.

- identifications are "biospecific", horizon by horizon (see text).

strongly punctuated succession of snapshots in the evolving history of two lineages. The biostratigraphy is strongly quantized. Few individual sections show more than a handful of faunal horizons and many have only one or two. Some faunal horizons can be followed widely and picked up in many sections, while others have been seen in only one or two. The list of faunal horizons described below has been accumulated from many localities and its time-ordered succession pieced together from partial sections by correlation.

How complete is this succession? There can be no definite answer. On the one hand, the evolutionary changes in the complete record would presumably have been continuous, so that no sharp boundaries between successive evolutionary stages would be expected in the fossil record. Yet it is just such boundaries at sharp breaks that are observed. Conversely, whether two fossil assemblages at two localities really are distinguishable or not, and hence to be regarded as strictly coeval or not, depends on the quantity and quality of the material available, both highly variable and neither ever perfect. It could well be, therefore, that some of the assemblages from different localities assigned to the same faunal horizon do in fact differ slightly in ages. Nevertheless, some relatively major faunal breaks remain and the question arises to what extent they reflect merely collection failure - ammonite beds present somewhere in the region but just not yet found - or represent true regional faunal non-sequences: periods of time during which ammonites were not present to leave a record. The indications are that our recording of the evidence regionally is tolerably complete. As more and more sections came to be recorded ever further afield, the discovery of new horizons became less and less frequent, and the same horizons kept on reappearing. Thus, nothing discovered in the North Sea (Callomon 1976, 1979, and numerous more recent collections) or in Svalbard (Rawson 1982) has added anything to the list of known horizons. It is only on going as far away as the Yukon (Poulton 1987) or arctic Siberia (e.g. Meledina 1973) that new faunas appear. Whether they fall into the gaps in Greenland or represent biogeographic subspecific contemporaries of known Greenland faunas remains to be seen and may never be determinable. 


\section{The ammonite faunal horizons}

The full systematic description of the faunas of East Greenland is a major task that has been in progress for some time. Its completion is however beyond the scope of the present account and has to be deferred. Fortunately, however, the majority of nominal species has already been described: the number of new nominal taxa to be formally defined is relatively few. What has been lacking has been the knowledge of stratigraphical succession, which is now available. All of the existing species have been recollected and their type-horizons are now known. It should therefore be possible to interpret the summary of the faunal succession given below by reference to existing figures and descriptions in the literature. The majority are in Spath's monograph (1932) and a revision of the legends to his plates, in Table I, gives the horizons and revised names of all his figures. The sections in Jameson Land in which faunal horizons have been recognized are shown schematically in fig. 4 . They are numbered more or less in ascending order from Hurry Inlet in the south to Antarctic Havn in the north (fig. 1). The relation of faunal horizons to the standard chronostratigraphical zonal classification of the Boreal Middle Jurassic is shown in fig. 2.

The status of faunal horizons as biostratigraphical units and the distinction from chronostratigraphical units was discussed on a previous occasion (Callomon 1985a). Each horizon is labelled by the name of its most characteristic species. The dimorphic status of the type of a species is indicated in the usual way: $[\mathrm{M}],[\mathrm{m}]$ for macro- and microconchs respectively. The problems of zoological nomenclature that arise in attempts to adopt a "vertical" classification of successive steps - transients in an evolving lineage have also been discussed elsewhere (Callomon $1985 \mathrm{~b}$ ), illustrated by numerous examples taken from the faunas discussed below. The choice of names to label what are in effect formally chronospecies is to some degree arbitrary, dictated largely by convenience and the desire to retain as far as possible an existing and well-established nomenclature. In many cases, successive transients already have separate names, which may be retained. In others, it is possible to resolve several transients within what has been classified together under a single name. In such cases it suffices to label such transients with an additional non-Linnéan symbol indicating relative stratigraphical horizons: $\alpha, \beta, \gamma \ldots$ This procedure is adopted here.

\section{Boreal Bathonian, Borealis Zone}

\section{Fauna 1. Cranocephalites borealis (Spath, 1932) $\alpha$ and $\beta$}

Holotype: Spath 1932, pl. 14, figs 4a-d, a nucleus, found loose at Hjørnefjeld by Rosenkrantz. It was his only specimen, despite the fact that the species is in fact very common and widespread. One locality alone at Ugleelv yielded over 200 specimens from a level of concretions. As with so many of the Greenland faunas, macroconchs dominate, here by at least 20:1.

Over most of Jameson Land, C. borealis is confined to a narrow interval. In southern Jameson Land, in the area of Hurry Inlet where it is most abundant, this interval can be reduced to a single layer of concretions. Further north, it may span a metre or two in otherwise barren quartz sandstones of the Pelion Member up to 100 metres thick. Only in a small area, in Ugleelv and Ræveelv north of Katedralen, has a succession of assemblages been found. The most extensive is in section 22, where $C$. borealis occurs at seven levels: at $42 \mathrm{~m}$ (no. 1), and between 61 and $99 \mathrm{~m}$ (nos. 2-7) above the base of the $101 \mathrm{~m}$ thick Pelion Member. Of these assemblages, nos. 2-7 are indistinguishable from the forms found elsehere in Jameson Land, which appear to be themselves everwhere the same. But assemblage no. 1 is different: the macroconchs are rather smaller and much more coarsely ribbed, retaining their ribbing on the bodychamber. It is therefore possible to distinguish two transients, $\alpha$ and $\beta$. The common, widespread form, including the type, is trans. $\beta$. To it belong most of the specimens figured reviously (Callomon 1959, pl. 17, figs 1, 2, pl. 18, fig. 3; 1985b, text-fig. 8A [M], $8 \mathrm{~b}$ [m]). Another dimorphic pair (Callomon 1984, fig. 2B [M], 2b [m]; 1985b, text-fig. 7B [M], 7b [m]) is trans. $\alpha$. As this transient has so ar been clearly recognized at only a single locality, it has not been entered in fig. 4 separately.

The species has also been found in Traill $\emptyset$ and described by Donovan under separate names (1953, C. kochi Donovan, p. 80, pl. 15, fig. 8 [M]; 
id. var. pygmaeus, p. 81 , pl. 16 , fig. 5 [m]; var. latus, p. 82, pl. 16, fig. 6 [M]; ?C. parvus Donovan, p. 79 , pl. 15 , fig. $2[\mathrm{M}])$.

This fauna, or very close contemporaries, makes a sudden widespread appearance throughout the Arctic. It seems to have been the first to colonize the entire region after a long period during which ammonites were absent, for the youngest faunas anywhere found below are of Aalenian or Early Bajocian age. Typical C. borealis is widespread in the Yukon ( $C$. warreni Frebold, 1958, from the Porcupine River; Poulton \& Callomon 1976, Poulton, Leskiw \& Audretsch 1982, from the Richardson Mountains), lying above either Pseudolioceras (Aalenian) or Arkelloceras (Lower Bajocian). It has also been described from the Anabar region of northern Siberia (C. kononovae, laptinskajae, sibiricum (Voronets, 1957); Boreiocephalites *pseudoborealis Meledina, 1967; sections given in Meledina 1973, p. 104). The species has been taken to be the first member of the family Cardioceratidae, which then inhabited the Arctic without break into the Kimmeridgian, a period of some 20 million years (Callomon 1985b). It so strongly resembles what must have been its immediate ancestors, Chondroceras of the late Lower Bajocian, that it cannot be much younger, hence presumed early Upper Bajocian.

\section{Indistinctus Zone}

Fauna 2. Cranocephalites indistinctus Callomon, 1959

[M]

Collections from two distinct horizons in the Ugleelv area differ slightly, but the material is not sufficiently well preserved to distinguish formally. The two assemblages are therefore simply labelled $\alpha$ and $\beta$, and assignment of individual specimens to one or other is in many cases based on stratigraphical position rather than on morphology. Of the specimens figured in 1959 , pl. 17, fig. 4 is $\alpha$, the others $\beta$. Microconchs are very rare (Callomon 1985b, fig. 8b). Found also in the Richardson Mountains of the Yukon (Poulton et al. 1982, p. 84) and on Prince Patrick Island in the Canadian Arctic Archipelago (Frebold 1958, pl. 8, figs 2, 3). There remains a considerable morphological jump from $C$. borealis to $C$. indistinctus (see Callomon 1985b figs 8A, B) suggest- ing a faunal hiatus, although there is no great thickness of strata in the interval in Greenland. Intermediate forms may be represented by e.g. Meledina's C. indistinctus (1973, pl. 4, figs 3a, b) from Anabar, although the stratigraphy is not well enough resolved (id., p. 104, bed $18,18 \mathrm{~m}$ ) to establish a sequence.

\section{Pompeckji Zone}

Ammonites of "the group of Cranocephalites pompeckji" also occur at many localities in Jameson Land between the head of Hurry Fjord in the south and Antarctic Havn in the north, sometimes in enormous numbers. Detailed examination of the collections show them to be made up of at least nine distinguishable faunal assemblages, each presumably representing a separate faunal horizon. Of these, six (nos. 3-8) have been clearly characterized stratigraphically in separable beds that can be recognized over some distances. The others, however, have been found so far at only one or two localities, and then on weathered slopes on which their individual beds could not be separated. They have therefore not been separately numbered but included in the descriptions of the better-characterized assemblages to which the seem to show the closest affinities, as sub-assemblages labelled (a), (b), etc. As a corollary, there remain considerable uncertainties in their stratigraphical order. Such uncertainties extend in part to some of the principal assemblages themselves, for as may be seen in fig. 4 , some of these, such as no. 6 , that of $C$. furcatus, known so far only from the region of Mikael Bjerg, have not been found in succession with any of the others. The order of succession shown in fig. 4 may therefore have to be revised one day.

Fauna 3. Cranocephalites sp. nov. A [intermissus MS]

A distinct assemblage, to be described, of large, involute and very inflated forms resembling fauna 5 , found so far only in section 21 on $\mathrm{Ka}-$ tedralen in a local lenticle of slightly crossbedded sandstone, above fauna 2 and below fauna 4 . 
Fauna 4. Cranocephalites gracilis Spath, 1932

with C. gracilis var. ornata Spath

C. maculatus Spath

var. tenuis Spath

var. transitoria Spath

[M]

[M]

[M]

[M]

Large collections from the eastern and northern slopes of Katedralen are made up of at least three closely related faunal assemblages that have so far been only partially resolved. They include all the forms brought back by Harris and described as new species and varieties by Spath, as well as some that are new.

\section{- 4a: Cranocephalites gracilis trans. nov. $\alpha$}

Small to medium-sized, evolute, compressed, almost serpenticone forms with strong, coarse primary ribbing that persists to the end of the mature bodychamber, the secondaries weakening or narrowly fading on a highly arched, rounded venter, tending to regenerate near the final peristome. There is a general overall resemblance both to $C$. gracilis and to $C$. distinctus (fauna 2). But the only collection of any size from a single bed (section 19, bed 6) contains no gracilis proper and lies well above the levels of $C$. indistinctus sedarated from them by beds correlated unambiguously with those of fauna $3, C$. intermissus, in section 21 . This assemblage $4 \mathrm{a}$ is overlain in section 19 by a bed (no. 7) yielding large, inflated forms of $C$. cf. and aff. maculatus. It occurs loose also at localities 20 and 21.

- 4b: Cranocephalites gracilis trans. $\beta$, s.s.

Found loose only at localities 20 and 21 , on the northern slopes of Katedralen. Collections made at successively higher intervals on the slopes at locality 21 suggest that this assemblage immediately follows $4 \mathrm{a}$, which occurs there at the lowest levels.

\section{- 4c: Cranocephalites maculatus}

This species is relatively rare and not enough material is so far available to be able reliably to estimate the intraspecific variability. It may include the large, inflated end-variants of several faunas. Specimens closely resembling Spath's type have been found only at localities 20 and 21 , where they occur together, but loose, with $C$. gracilis, perhaps a little higher. Similar, but perhaps slightly different forms occur at locality 19 (bed 7) clearly above fauna 4 a. C. gracilis var. ornata appears to be morphologically intermediate between $C$. maculatus and $C$. gracilis, and for this reason $C$. maculatus has been attached here to $C$. gracilis rather than to other larger, inflated species, such as $C$. carlsbergensis.

Some previously described forms are hard to place. C. maculatus var. transitoria has also been recollected at locality 21 . It is characterized by the strong, coarse, relatively sharp ribbing that persists without fading on the adult bodychamber. $C$. maculatus var. tenuis shares this feature but is smaller and develops a narrow, smooth band on the adult venter. Both forms are rare and not at present linked via intermediates to the more familiar species, of which, however, they may be merely extreme variants. On the other hand, there may be yet further distinguishable faunal horizons to be resolved here.

\section{Fauna 5. Cranocephalites sp. nov. B [carlsbergensis MS]}

with ? C. inversus Spath

? C. inconstans Spath

? C. subbullatus Spath

? C. subextremus Spath

? C. pompeckji var. laevis Spath var. intermedia Spath

Another distinct, well-defined assemblage represented by large collections of well-preserved adults from Trefjord Bjerg, section 39 (fauna 5a). Some specimens have been figured previously (Callomon 1976, fig. 6C, 1985b, figs 8C [M], 8c [m]). The characteristic features are large size, coarse primary ribbing tending to circumbilical bullae, and secondary ribbing that fades, leaving the external side of the bodychamber smooth. The four new species created by Spath are all based on types too poorly preserved to be closely identifiable. They are part of a collection made by Whittard in 1929 at Antarctic Havn during the Cambridge expedition of that year (Parkinson \& Whittard 1931) and came from a single bed about a metre thick in an immense succession of barren sandstones. The locality has been rediscovered (sections 84-86) but newly collected material is no better than what was available previously. 
Doubts remain, therefore, whether this assemblage really is identical with that of $C$. carlsbergensis, and this could be expressed formally by retaining a separate assemblage (5b) of $C$. subbullatus Spath. But for general purposes it seems preferable to discontinue the use of these ill-defined names and to introduce a new one based on good, well-dated material.

The fauna has been met with repeatedly in borings in the North Sea (e.g. Callomon 1976). It is probably represented in the Canadian Arctic (Frebold 1958, pl. 7, figs 1a-c), and closely similar, if not identical, assemblages occur in northern Siberia (C. vulgaris Voronets, Meledina, non Spath: Voronets 1962, pl. 5, fig. 1; Meledina 1973, pl. 2, fig. 1, pl. 3, fig. 1). A similar but separate assemblage appears to be represented there by C. nordvikensis Voronets (1962, pl. 6, figs 1, 2, pl. 12, fig. 5; Meledina 1973, pl. 4, fig. 8, pl. 10, fig. 1).

Fauna 6. Cranocephalites furcatus Spath, 1932

incl. C. furcatus var. pygmaeus Spath

C. pompeckji var. rustica Spath var. costata

Slimmer, more evolute forms retaining coarse, blunt bifurcating ribbing on the bodychamber. Similar but not identical forms seem to occur in Siberia e.g. Meledina's $C$. nordvikensis (1973, pl. 5, fig 3. ?pl. 3 fig. 3).

The stratigraphical position of this fauna is uncertain. It is widespread around Mikael Bjerg, sections 29-37, where however none of the other faunas have so far been positively identified. Conversely, it appears to be absent around Katedralen if we discount one or two specimens of the correct morphology, found loose, that may be merely extreme variants of one of the other faunas. The species as a whole closely resembles $C$. gracilis (fauna 4), but there are consistent differences in the style of ribbing, the quadrate whorlsection, and the morphology of the inner whorls, which are closer to those of $C$. pompeckji.

Fauna 7. Cranocephalites pompeckji (Madsen, 1904) with C. vulgaris Spath

var. compressa Spath
var. densicostata Spath
var. inflata Spath
var. robusta Spath

The species was based on five syntypes collected by Nordenskjøld and Harz during the Danish expedition of 1900 . Madsen's pl. 8, fig. 6 was selected to be the type by Spath $(1932$, p. 17). The locality, "Ammonite Mountain", must have lain somewhere north of Sortehat (section 24) if the elevation of $500 \mathrm{~m}$ is to be believed. Certainly, Madsen's type can be matched in a stratigraphically well-defined assemblage that occurs in profusion all round upper Ugleelv and on Katedralen, whence came also $C$. vulgaris and its varieties. Other topotypes have been figured in Callomon 1985b, fig. 4; fig. 8D [M], 8d [m].

Also found in the Yukon (Poulton et al. 1982), Prince Patrick Island (Frebold 1958, pl. 8, fig. 1), Novaya Zemlya (Sokolov 1913, pl. 1, fig. 2) and northern Siberia (Voronets 1962, pl. 7, fig. 1).

\section{Fauna 8. Cranocephalites sp. nov. C [episcopalis MS]}

Very large, inflated forms strongly and densely ribbed to large diameters, sometimes to the end, sometimes becoming smooth on the bodychambers. The available material is not great and is rather poorly preserved, but the morphology is so distinct that it cannot be mistaken. The type locality is in Ugleelv (section 21) but there was no difficulty in recognizing the fauna again in another isolated section on Pelion, section 58. The closest figures in the literature appear to be again of specimens from Siberia (Meledina 1973, pl. 2, fig. 2, pl. 3, fig. 2, pl. 5, fig. 2).

There is again no direct evidence of the relative stratigraphic position of this fauna other than that it lies above $C$. carlsbergensis, fauna 5. Morphologically, however, it has already almost as much in common with the earliest forms of Arctocephalites above as it does with typical Cranocephalites, especially in the wide variability of inflation and large size. For this reason it is placed here at the top of the Pompeckji Zone. 


\section{Arcticus Zone} Fauna 9. Arctocephalites arcticus (Newton,
1897)

with A. koettlitzi (Pompeckj)

A. ellipticus Spath

A. pilaeformis Spath

$A$. nudus Spath

A. elegans Spath

A. ornatus Spath

A. sphaericus Spath var. pleurophora Spath

A. platynotus Spath

This fauna marks a change in direction in the evolution of the Cardioceratidae, towards forms that are predominantly compressed, highly involute, densely and finely ribbed on the inner whorls and wholly smooth on the adult bodychamber. At the same time the intraspecific variability of the inflation of the shell greatly increases, ranging at every level from compressed to sphaeroconic. These changes have been conventionally indicated by a change of generic name, although the transition is phyletic, not phylogenetic. Fauna 9 is intermediate but already highly variable. The first four species were from Windy Gully on Franz Josef Land and appear to be from the same horizon, although this is not proven (Newton \& Teall 1897, Pompeckj 1900, Whitfield 1907). The remaining six forms all came from a single horizon, half a metre thick, in Jameson Land, rediscovered and recollected in 1971 (section 35), and there are intermediates between all the extremes of variability represented by elegans (compressed), nudus (smooth) and sphaericus (inflated), including specimens that match very closely the forms from Franz Josef Land. Hence the same name is used for both assemblages, even if they are not quite identical. Additional figures in Callomon 1985b, fig. 8E [M], 8e [m] (= Callomon 1976, fig. 5E). Siberia: Meledina 1973, pl. 12.

\section{Fauna 10. Arctocephalites sp. nov. $D$ [delicatus MS]}

with $A$. cf./aff. sphaericus Spath

Callomon 1985b, fig. 8F [M], 8f [m]. Typically rather small, compressed forms with very small umbilicus and rounded venter, dense but sharp ribbing retained to later stages than in the fauna below. There is again a tail in the distribution, of inflated forms up to nearly spherical. But the most significant change is in the microconchs, which are now evolute, compressed and densely ribbed to the end, a style changing little until well up in the Callovian and previously often described under the name Pseudocadoceras or, for the early forms, Costacadoceras Rawson, 1982. ?Novaya Zemlya: Salfeld \& Frebold (1924), pl. 1 , fig. 1.

The differences between faunas 9 and 10 are again large enough to suggest a considerable faunal hiatus in Greenland. What may be the missing intermediates have been described from the Yukon (Poulton 1987, as A. spathi, A. porcupinensis and $A$. arcticus in part, Spathi and Porcupinensis Zones).

\section{Greenlandicus Zone}

Three faunas dominated by large, compressed and highly involute forms, still finely and densely ribbed on the inner whorls, becoming smooth.

\section{Fauna 11. Arctocephalites sp. nov. E [micrumbilicatus MS]}

Predominant morphology disc-like, with minute umbilicus and arched venter; larger than the forms in fauna 10; occasional variants again large and inflated.

Fauna 12. Arctocephalites greenlandicus Spath, 1932

with A. crassum (Madsen, 1904)

$A$. spp. aff. crassum

Callomon 1985b, fig. 8g [M], 8g [m]. Larger, more evolute and more coarsely-ribbed to greater diameters than fauna 11 . Widely recognizable throughout south and central Jameson Land. The types of greenlandicus (compressed) and crassum (inflated) came from Katedralen (Ugleelv) and Vardekløft (southern Hurry Inlet) respectively, but new collections from both localities are sufficiently numerous to leave little doubt that the 
two "species" came from the same horizon; and intermediates show that they are merely the extreme variants of a single biospecies. The microconchs are now also relatively large, evolute and still finely ribbed. The Greenlandicus Zone is almost certainly present both in Siberia and the Yukon, represented by such forms as $A$. kigilakhensis Voronets, 1962 (pl. 9, fig. 3; Meledina 1973, pl. 17, fig. $1[\mathrm{M}]$, pl. 18 , fig. $3[\mathrm{~m}])$ and $A$. frami, amundseni Poulton, 1987 (pls. 12, 13), but the faunas do not seem to be identical.

Fauna 13. Arctocephalites freboldi (Spath, 1932)

with $A$. cf. greenlandicus, late form

$A$. aff. crassum

Large, fairly evolute, strongly and coarsely ribbed; inflated forms now predominate. Only the inner whorls were figured by Spath (holotype, pl. 18, fig. 2a, b), but a cast of the whole specimen, which is septate to $100 \mathrm{~mm}$ with the bodychamber just beginning, has been illustrated by Poulton (1987, pl. 16, fig. 1, 2). Possibly represented in the Yukon by $A$. belli Poulton and his $A$. cf. freboldi, sp. $A$, sp. $B$ (pls. 14, 17).

\section{Ishmae Zone}

Fauna 14. Arcticoceras harlandi Rawson, 1982

A. cf. excentricum Voronets, 1962

A. (Costacadoceras) bluethgeni Rawson, 1982

Very large, coarsely-ribbed forms, the primaries accentuated low on the whorl-side, the secondaries becoming accentuated on the arched venter - taken arbitrarily as the distinction between Arctocephalites and Arcticoceras - without however yet sweeping forward. Inflated variants now quite evolute. Microconchs also large, strongly ribbed. The pair $A$. harlandi/A. bluethgeni give as clearcut an example of dimorphism as could be wished for. The type material came from a beautifully-preserved and abundant assemblage found in Kong Karls Land, Svalbard. Material from Jameson Land is less well-preserved, but sufficient to leave identity with the Svalbard assemblage in little doubt. The specimens from the
Yukon figured by Poulton (1982, pls. 19, 20) under the same name seem identical. Petshora: Meledina 1987.

\section{Fauna 15. Arcticoceras ishmae (Keyserling, 1846) $\alpha$}

The first of two successive assemblages differing in details - see below.

Fauna 16. Arcticoceras ishmae (Keyserling, 1846) $\beta[=$ s.s.]

with

$$
\begin{array}{r}
\text { A. kochi Spath } \\
\text { var. pseudolamberti Spath }
\end{array}
$$

A. michaelis Spath

A. pseudishmae (Spath) [inflated var.][M] Oxycerites cf. birkelundi Poulton, 1987

Callomon $1985 \mathrm{~b}$, fig. $8 \mathrm{H}[\mathrm{M}], 8 \mathrm{~h} \cdot[\mathrm{m}]$. This, one of the most venerable of Arctic ammonites, had until quite recently to rely for its interpretation largely on a topotype in London figured by Spath (1932, pl. 15, figs 7a, b; refigured by Krymholts et al. in the Russian Osnovy, Luppov \& Drushchits 1958, pl. 31, figs 6a, b), obtained from Krantz in 1897 . The specimen originally described by Keyserling (1846, pl. 20, figs 8,9 only) has now been refigured (in Saks et al. 1976, pl. 9, figs 1a, b, and in Krymholts, Mesezhnikov \& Westermann 1988, pl. 6, figs 1a, b). It was one of several syntypes, not holotype as stated in the legends of the refigurations, and any residual doubts are now removed by formally designating it lectotype. The similarity between it and Spath's specimen is extremely close. In both fauna 15 and 16 compressed variants dominate, although as usual there is a minority of inflated forms, the extremes being almost spherical. The ribbing is sharp and.strong, with now a pronounced forward sweep of the accentuated secondaries on the sharply arched venter, slightly more so in fauna 16 than in 15 ; the forms of fauna 16 are also somewhat smaller and become smooth on the adult bodychambers rather earlier. The holotype and probably most of the rest of the type-series of A. kochi came from fauna 16 , as do the variants most closely resembling the lectotype and Spath's specimen of $A$. ishmae. Furthermore, the type of $A$. kochi is somewhat crushed and otherwise poorly preserved, in no fit state to uphold a well- 
defined, independent species. Hence $A$. kochi is treated as no more than a junior synonym of $A$. ishmae s.s. These relationships have become clear only through new and stratigrahically controlled collections, made after $A$. koch $i$ had become index of the Kochi Zone. This should therefore also be renamed Ishmae Zone. Other specimens from Greenland have been figured by Callomon (1976, fig. 5B) and Callomon \& Wright (1989, fig. 6).

This is one of the commonest and most widespread faunas in the Arctic. Northern North Sea (Callomon 1976); northern Russia (Petshora, Keyserling 1846, Sokolov 1912, Meledina 1987); Novaya Zemlya (Meledina 1973); northern Siberia (Lena-Anabar, Meledina 1973); Yukon (see discussion in Callomon 1984, p. 165, fauna C8).

Of special interest is the appearance at this level of the genus Oxycerites, otherwise usually restricted to more temperate or tropical "Tethyan" latitudes. Specimens from Greenland have been figured by Birkelund et al. (1971, pl. 1, pl. 2, figs 1-5). Very similar specimens, from almost identical levels in the Yukon, were described under the name $O x$. birkelundi by Poulton (1987). Ox. undatus and jugatus Ershova \& Meledina, 1968 (redescribed by Meledina, 1973) from northern Siberia appear to be a little older, from either the Arcticus or Greenlandicus Zones.

\section{Fauna 17. Arcticoceras sp. nov. F}

\section{[crassiplicatum MS]}

Typically compressed forms with relatively open umbilicus and acute venter, as in $A$. ishmae, but with now very coarse and strong ribbing which persists ventrally on the whole of the adult bodychamber. Has been found at several localities, from Hurry Inlet to Mikaels Bjerg, but is almost always fragmentary or crushed. The only record elsewhere so far appears to be in the Yukon (Callomon 1984, p. 165, fauna C8(c)).

\section{Cranocephaloide Zone}

Fauna 18. Arcticoceras cranocephaloide Callomon \& Birkelund, 1985

with Kepplerites sp. nov. G [stephanoides MS] K. tychonis var. fasciculata Spath, 1932 (pl. 26, fig. 6)
Text-fig. 3; Callomon 1985, fig. 8I [M], 8i [m]. Late forms of Arcticoceras beginning to be transitional to Cadoceras, particularly in the inner whorls which are evolute with open umbilicus, and the microconchs, which can be almost serpenticone. The adult bodychambers are ribbed to the end and round-whorled; found as fragments, they strongly recall Cranocephalites (see fig. 3).

This horizon sees the first appearance, suddenly and in quantity, of the Kosmoceratidae. These early forms are round-whorled at all stages, both in macro- and microconch, and could equally well be placed still in Cadomites [M]/ Polyplectites [m], themselves descendents of Stephanoceras. Similarly small, round-whorled, densely-ribbed forms still resembling Cadomites make an equally abrupt first appearance at about the same level in the Western Interior of North America (see Callomon 1984, p. 153, fauna A5, Kepp. costidensus (Imlay, 1953)). In the Yukon, what appears still to be true Cadomites occurs as high as the lower Ishmae Zone (Poulton 1987, pl. 29, figs 20-23).

Fauna 19. Kepplerites tychonis Ravn, 1911

\section{with Arcticoceras aff. cranocephaloide}

The name tychonis has hitherto been applied indiscriminately to numerous forms of Kepplerites found in the Arctic and in North America (e.g. by Spath), in the absence of stratigraphical details. The type (Ravn 1911, pl. 37, figs 1a-e, refigured by Imlay 1975 , pl. 5, fig. 4, pl. 6, fig. 6, for comparison with forms from southern Alaska) was found loose on Store Koldewey, $600 \mathrm{~km}$ north of Jameson Land. The true $K$. tychonis has since been found in abundance and in succession in Jameson Land, and at one locality in Milne Land (Callomon \& Birkelund 1980, pl. 1, fig. 3 [M], $4[\mathrm{~m}]$. The microconchs now have sharply tabulate venters, as in Kosmoceras, but no ventro-lateral tubercles. The Arcticoceras was also illustrated from Milne Land (ibid., pl. 1, fig. 1a, b $[\mathrm{M}], 2 \mathrm{a}, \mathrm{b}[\mathrm{m}])$.

\section{Variabile Zone}

Fauna 20. Kepplerites sp. nov. $H$ [inflatus MS]

with Arcticoceras sp. 
Cadoceras cf. or aff. variabile Spath

The Keppleritids resemble $K$. tychonis in style of ribbing but are much more inflated, some with almost spheroconic inner whorls. The Arcticoceratids are highly variable, some beginning to develop on the umbilical margin in the adult macroconch bodychamber the sharp edge usually taken as the differentiating character of Cadoceras.

Fauna 21. Kepplerites rosenkrantzi Spath, 1932

with Arcticoceras sp. nov. I Cadoceras variabile Spath, 1932

(cf. Callomon 1985b, figs 8J, j)

C. ventroplanum Voronets, 1962

C. subcatostoma Voronets, 1962

C. cf. or aff. barnstoni (Meek)

C. aff. calyx Spath and spp.

This assemblage may be a mixture of two faunas of slightly differing ages that could not always be separated in the field. The Arcticoceras is small, involute and compressed, and seems genuinely to be the last representative of the genus, not connected at this horizon with coeval Cadoceras through intermediates. The Cadoceras now have the coiling characteristic of the genus but retain the coarse, strong ribbing of Arcticoceras. $C$. barnstoni is a Canadian species and has been redescribed from the Yukon, where it is abundant (Poulton 1987). Arctic Russia: Kanin Peninsula (Meledina 1987).

\section{Calyx Zone}

Fauna 22. Kepplerites peramplus Spath, 1932 $?=K$. antiquus Spath, nobilis Spath

with K. svalbardensis Sokolov \& Bodylevsky, 1931

Cadoceras cf. franciscus Spath

C. cf. victor Spath

C. aff. variabile Spath

C. perrarum Voronets

The Keppleritids seem to fall into two quite separate groups, the huge, involute, compressed peramplus probably representing a local element. Other specimens were figured in Dietl \& Callomon 1988 (figs 3-5) for comparison with a very similar specimen found in the Upper Bathonian, Orbis Zone of the Franconian Alb in Germany. The Cadoceratids are relatively small, with inflated bodychambers.

Fauna 23. Kepplerites vardekloeftensis sp. nov. (=K. tychonis Spath non Ravn)

with Cadoceras victor Spath

C. calyx

C. franciscus Spath

C. ammon Spath [a juvenile]

This is the horizon of the "tychonis beds" of Spath, a prominent level of calcareous, concretionary siltstone that can be followed all along Neills Klinter, the cliffs that border the western shore of Hurry Inlet. It forms the top bed of the Fossilbjerget Member proper of the Vardekløft Formation and marks a non-sequence below the immediately overlying Wood Beds, of late Lower to Middle Callovian ages. Overlooking Rosenkrantz's principal camp-quarters in the years 1926-7, it provided an exproportionately large component of the faunas described by Spath. The type of $K$. vardekloeftensis is Spath's $K$. tychonis, pl. 25, fig. 2, a fine complete adult, with the other specimen, fig. 1 , as paratype. The coiling is slightly more evolute than in $K$. tychonis, the whorl-section more inflated and rounded, the adult size larger; but the ribbing is still fine and dense, with fasciculate secondaries dividing inconspicuously low on the whorl-side. The macroconchs have inner whorls that are still almost round-ventered, with only a hint of flattening. The microconchs are compressed with narrow, flat venter bordered by sharp, angular ventrolateral margins but no tubercles. The adult peristome has a long, slender lappet. There is a strong resemblance to Kosmoceras pauper Spath (1932, p. 96 , pl. 24, fig. 3a, b), but as Spath himself pointed out, the closest resemblance of this holotype and only known specimen is to the microconchs of the English upper Calloviense Zone, Enodatum Subzone. It was said to have come from the "tychonis bed" west of Harris Fjeld, at the northern end of the Neills Cliff outcrops, but in this area the bed has become rather unfossiliferous. It may well have come from a concretion in the Wood Beds above, which are there well exposed and which have yielded Calloviense 
Zone ammonites. None closely like it have been rediscovered during the renewed search of the "tychonis bed". The species $K$. pauper is therefore best kept separate for the time being, as of uncertain age.

The commonest Cadoceras in this fauna is $C$. victor, probably the largest species of Cadoceras known. Inner whorls are evolute, the umbilicus in the adult open: $C$. calyx is merely an extreme variant. The ribbing fades fairly early, but traces of the primaries remain as crenulations on the sharp umbilical edge. Additional figures in Callomon 1985b (fig. 8K [M], 8k [m]).

\section{Lower Callovian, Apertum Zone}

Faunas 24-26. Cadoceras apertum Callomon \& Birkelund $1985 \alpha, \beta, \gamma$

with $C$. cf. or aff. frearsi (d'Orbigny) Kepplerites cf. or aff. keppleri (Oppel)[M] K. traillensis Donovan, 1953

Three faunas found in rapid succession, clearly distinguishable in the field and morphologically when material is plentiful; but there is so much overlap of variants that individual specimens may be hard to assign, especially among the rather featureless Cadoceratid macroconchs. The forms of this genus are now highly evolute, some of the microconchs of transient $\gamma$ becoming roundwhorled serpenticones like Perisphinctids (for additional figures see Callomon 1985b, fig. 8L [M], $8 \mathrm{I}[\mathrm{m}])$. Of all the Cadoceratids known from Greenland and Britain, it is those from these horizons that most closely resemble d'Orbigny's Amm. frearsi (1845, p. 444, pl. 37, figs 1, 2). The type appears to be lost, so we are dependent on the first reviser, who was Nikitin $(1885$, p. 55). He pointed out that even the locality given by d'Orbigny - Khoroshovo, near Moscow - could not be correct, for the earliest beds there are Volgian in age. He described new material, including a specimen, refigured by Sazonov (1957, p. 106, pl. 4, figs 1, 1a, from Elatma), that was designated neotype by Callomon and Birkelund (1985, p. 82, with full discusssion). The species occurs in the Elatmae Zone of the Russian Platform; and the age of this is now firmly established as early Lower Callovian through the affinity of C. elatmae with $C$. quenstedti, which occurs in the lowest, Keppleri Subzone of the basal Herveyi Zone (Callomon, Dietl \& Niederhöfer 1989).

The Keppleritids are not sufficiently numerous to show whether the Greenland fauna matches that of the type fauna of $K$. keppleri in Swabia across the whole range of variability, but some variants match European specimens exactly. There can be little doubt that the relations are very close. The type horizon of $K$. keppleri has now been precisely established in Swabia and is characterized by a rich accompanying fauna of Macrocephalitids, Oppeliids, Bullatimorphitids and Perisphinctids (Callomon et al. 1989 cit. sup.). It is being proposed as the basal faunal horizon in defining the basal boundary stratotype of the Callovian Stage. The horizons of $C$. apertum are therefore also taken to mark the base of the Callovian in Greenland, although how closely this coincides with the stratotype cannot be determined with a precision greater than that which the faunal correlations permit - as in all correlations.

Fauna 27. Kepplerites sp. nov. J [tenuifasciculatus MS]

A distinct horizon found in the Mikael - Fossilbjerget area of central Jameson Land, in which Keppleritids dominate almost to the exclusion of Cadoceratids. The forms are more evolute than $K$. keppleri. The style of ribbing is similar but much finer and denser.

Fauna 28. Cadoceras (Paracadoceras) cf. or aff. breve Blake, 1905

\section{with Kepplerites aff. traillensis Donovan}

Found in the area around Olympen. Material is fairly abundant but rather poorly preserved, and perhaps of slightly different ages at different places; but the identification of the small, evolute, smooth Paracadoceras seems secure. The type horizon of $C$. breve in Dorset lies some way up in the Upper Cornbrash, still in the siddingtonensis brachiopod zone (Douglas \& Arkell 1928), which occasional Macrocephalitids indicate to be the upper part of the Keppleri Subzone of the Herveyi Zone. In the North American Cordillera Paracadoceras occurs at a similar level, immediately above Kepplerites loganianus, 
the local equivalent of $K$. keppleri (Callomon 1984 , p. 160 , fauna B8(b)).

\section{Nordenskoeldi Zone}

\author{
'Faunas 29-30. Cadoceras nordenskjoeldi \\ Callomon \& Birkelund $\alpha, \beta$ \\ with C. (Paracadoceras) sp. indet. \\ C. (Pseudocadoceras) sp. \\ Kepplerites aff. traillensis
}

All the available material is more or less crushed, but the evolute and coarsely-ribbed $C$. nordenskoeldi is highly characteristic and hard to mistake. The first specimen to be found was collected by Nordenskjøld and described by Madsen as a Perispinctid, Olcostephanus sp. Two successive faunas are clearly distinguishable in the field, the lower (a) being somewhat less coarsely ribbed, resembling still the evolute but regularly ribbed forms of the probably ancestral $C$. apertum. C. nordenskoeldi : appears to represent a local fauna that died out abruptly, leaving no descendents. It is quite distinct from the associated Paracadoceras; which represents the long-ranging mainstream of the evolving Cadoceratid lineage.

\section{Koenigi Zone}

\section{Fauna 31. Cadoceras septentrionale Frebold, 1964}

Callomon 1985b, fig. 8M [M], $8 \mathrm{~m}$ [m]. The type series came from Axel Heiberg Island in the Canadian Arctic Archipelago. The resemblance of the Greenland assemblage is close, over the whole range of variability; cadicones predominate. May be represented in Siberia. There is now also a growing resemblance to the earliest fauna of Cadoceras found in Britain in the Koenigi Zone, although they are not the same the Greenland forms, having consistently more open umbilici. In the absence of Keppleritids it is difficult to correlate the fauna more closely with those of Europe. It is therefore placed somewhat arbitrarily already in the Koenigi Zone. The base of this

has itself not yet been formally defined, because of remaining unresolved problems of correlation even in Europe (see Callomon et al. 1989).

Fauna 32. Kepplerites cf. gowerianus (Sowerby)

with $K$. cf. metorchus Buckman

$K$. (Torricellites) cf. approximatus Buckman

Cadoceras cf. tolype Buckman

C. (Pseudocadoceras) cf. grewingki Pompeckj

Proplanulites cf. laevigatus Buckman

The abundantly fossiliferous sandstones and shales with concretions of the Apertum-Nordenskjoeldi Zones in central Jameson Land are followed by a considerable thickness of silty to fine-grained sandy shales with almost no hard beds. Even if they do contain ammonites, these cannot be recovered because of weathering. The material in the present fauna came from two localities. The first lies in one of the rare indurated lenticles in these shales in section $68, \mathrm{SSW}$ of the summit of Olympen. The second lies in a bed of more substantial sandstone that has come in, west of Olympen, in section 74 . The specimens in the first sample are crushed and poorly preserved, but the Keppleritids show the characteristic evolute coiling, small size and dense ribbing of $K$. gowerianus, typical of the group referred to the subgenus Gowericeras that marks the beginning of the Koenigi Zone in Europe. The second sample is larger and better preserved. Its Keppleritids are closer to $K$. metorchus, which in England is perhaps a little older than $K$. gowerianus s.s. (Callomon, Dietl \& Page 1989). The Greenland material is however insufficient to make a distinction, and both samples are therefore assigned to the same faunal horizon.

\section{Fauna 33. Chamoussetia phillipsi Callomon \& Wright, 1989}

with Kepplerites (Gowericeras) cf. trichophorus Buckman, 1922

$K$. (Toricelliceras) sp.

Cadoceras sp. cf. or aff. sublaeve

[M]

(Sowerby)

Proplanulites sp. 
This fauna correlates closely with those of the Curtilobus Subzone of the Koenigi Zone, especially from Yorkshire, recently revised by Page (1989). It may be represented in the Petshora by Chamoussetia stuckenbergi (Lahusen, 1875) (see Callomon \& Wright 1989), where the Keppleritids appear however to be absent.

\section{Fauna 34. Kepplerites galilaeii (Oppel, 1862)}

with $K$. (Toricellites) cf. curticornutus (Buckman)

Cadoceras sp. nov. $J$ [coriniense MS] [M]

C. (Pseudocadoceras) cf. grewingki Pompeckj

Proplanulites (Crassiplanulites) cf. crassicosta Buckman, 1921

P. (Proplanulites) cf. petrosus Buckman

Found in a bed about a metre thick cropping out widely to the west of Olympen as far as Kosmoceras Bjerg, bearing an astonishing resemblance both in fauna and facies to the classical Kellaways Rock of Wiltshire. As there, the succession is condensed and several faunal horizons occur in quick succession, their resolution having been achieved only recently (Callomon, Dietl \& Page, 1989). K. galilaeii is morphologically transitional to Sigaloceras, beginning to show involute, compressed inner whorls with tabulate venter and dense, fine ribbing. The Cadoceras is a form characteristic of the Galilaeii Subzone: relatively compressed, with arched venter, small, and becoming wholly smooth at already early stages. It was noted by Spath (1932 (p. 60) and referred to as the "English form of $C$. tchefkini, d'Orbigny sp.", to which it certainly bears a strong resemblance, but the true tcheffkini (d'Orbigny 1845 , pl. 35, figs 10-15, refigured by Douvillé 1911, no. 214, from Elatma) comes from the Middle Callovian (Nikitin 1881, p. 64).

\section{Calloviense Zone}

Fauna 35. Sigaloceras calloviense (J. Sowerby, 1815)

with $S$. (Guliemina) quinqueplicata Buckman

Cadoceras cf. sublaeve (J. Sowerby)
Faunas 34 and 35 could often not be clearly separated in the field. They are most profuse by far in a bed of hard sandstone, about a metre thick, that crops out only around Kellaways- and Kosmocerasbjerge, sections $75-78$. The bed is locally divisible into up to five thinner units (a)-(e) separated by sharply-defined partings. These subunits may be cross-bedded. They are traversed by vertical burrows to depths of $0.5 \mathrm{~m}$, crossing the partings. The fossils occur in nests, almost always in the top one or two units, the ammonites embedded at all angles. As an exception, in section 74 the ammonites are from the middle of the bed. Here they are however demonstrably older, fauna 32 above. Sedimentation must therefore have been rapid but highly sporadic. Yet the sediments must have remained unconsolidated and vulnerable to bioturbation for almost the whole of the time interval of their accumulation, shown by the ammonites preserved in them to represent a period equivalent to the whole of an ammonite Subzone, perhaps 300000 years. The inability to separate some of the faunas stratigraphically in the field is therefore not surprising. That the two faunas really are of different ages has been clearly established in England, where the distinction between $K$. galilaeii and $S$. calloviense is clear-cut. The forms of the latter from Greenland are not identical with the English type faunas, but are .very... close. They differ mainly in being slightly more evolute and compressed. The fine, dense ribbing and tabulate venters are the same. The difference in age of the two faunas is confirmed in Greenland by the fact that their relative abundances in the collections vary widely from place to place.

The horizon of S. calloviense is one of the most widely recognizable: from East Greenland, via Britain and northern France to southern Germany, eastwards across much of the Russian Platform (Meledina 1987) to the Caucasus (Lominadze \& Sakharov 1985).

\section{Middle Callovian}

Fauna 36. Kosmoceras cf. or aff. jason (Reinecke)

with $K$. cf. or aff. guliemi (Sowerby) [m] Cadoceras aff. anabarense Bodylevsky, 1960 or aff. milaschevici (Nikitin, 
1881)

C. (Pseudocadoceras) cf. laminatum

Buckman or cf. concinnum

Buckman

$[\mathrm{m}]$

The post-Calloviense beds in Jameson Land, although thick, become sparsely fossiliferous. Ammonites, usually poorly preserved, are found at scattered and stratigraphically widely separated localities. Even so, they appear to have colonized the region at only a few times, so that only some of the Zones of the Middle and Upper Callovian have been recognized at all. The fauna listed above seems to indicate one reasonably coherent assemblage. The Kosmoceratids occur around Olympen and Parnas in beds that are transitional to the Olympen Formation; the Cadoceratids came mainly from further south, from shales or the Wood Beds in the upper part of the Vardekløft Formation. Attempts to identify the macroconch more closely are hindered by the absence so far of a systematic description of the Cadoceratids of the early Middle Callovian of Europe.

\section{Upper Callovian}

Fauna 37. Longaeviceras keyserlingi (Sokolov, 1912)

with $L$. cf. or aff. stenolobum (Keyserling, 1846)

Kosmoceras cf. fibuliferum (Buckman, 1924)

Kosmoceras cf. phaeinum (Buckman, 1924)

Quite well-preserved material has been found at one narrow horizon around Kosmocerasbjerg, west of Olympen, and what appears to be the same fauna occurs in the hills around Antarctic Havn and in Milne Land. The Longaeviceras seems to be identical with the fauna described from the Petshora by Sokolov. It can become huge (cf. Sokolov's pl. 1, fig. 3a-d: L. nikitini is a synonym of $L$. keyserling $i$ ) and has the characteristic acute venter on the inner whorls. (The nomenclature of $L$. stenolobum is complicated by Sokolov's attempt to attach Keyserling's name to a specimen that was not a syntype: see discussion by Bodylevsky 1960 , p. 77 , who in turn designated as lectotype a specimen that has yet to be figured). The Kosmoceratids are most closely similar to those found in the lower Athleta Zone of Britain and northern France, in the Phaeinum Subzone of the British standard zonation.

The intraspecific variability is considerable. One of the forms with fine, dense spinose ribbing on the inner whorls was figured from Milne Land by Callomon and Birkelund (1980, pl. 2, fig. 1); another, with "looped" secondary ribbing, as in $K$. phaeinum itself, from northern Jameson Land, by Birkelund, Håkansson and Surlyk (1971, pl. 2, fig. 6). As at other levels, this fauna from central East Greenland represents a mixture of elements from two faunal provinces, the Subboreal (Kosmoceras) and truly Boreal (Longaeviceras). In the Subboreal proper, in Britain, Longaeviceras is uncommon and Kosmoceras dominates. In the Boreal proper, e.g. in the Petshora, Kosmoceras is extremely rare (Meledina 1987, ? pl. 8, figs 1, 2, 4).

\section{Higher faunas: Oxfordian}

Scattered finds of Cardioceratidae in Jameson Land indicate Lower and Middle Oxfordian:

\section{Fauna 38. Quenstedtoceras woodhamense Arkell, 1939}

Valley in the south slopes of Olympen, an isolated level in thick Olympen Formation. Mariae Zone, Scarburgense Subzone

\section{Fauna 39. Cardioceras alphacordatum Spath, 1939}

River-bank in the area of lower Depot Elv, central Jameson Land, in shales laterally equivalent to Olympen Formation. Mariae Zone, Praecordatum Zone.

Fauna 40. Cardioceras cf. densiplicatum Boden

Scattered finds in the higher parts of the Olympen Formation around Olympen (e.g. Birkelund et al. 1971, pl. 2, figs 7-9) and on Mikaels Bjerg. 
Densiplicatum Zone, Vertebrale Subzone of the Middle Oxfordian.

\section{Fauna 41. Decipia cf. decipiens (Sowerby)}

The lowest fauna found in the Hareelv Formation in Neills Klinter on Hurry Inlet, and at scattered localities further inland to the west. Upper Oxfordian, Glosense Zone, equivalent to fauna 9 of Milne Land (Callomon and Birkelund 1980).

The Upper Jurassic faunas of East Greenland, including those of the Oxfordian, are best developed in Milne Land, which provides the regional standard of reference. For comparison, the levels of the first ten faunal horizons of Milne Land have been included in fig. 2. Kimmeridgian and Volgian faunas are sparse and scattered in Jameson Land. Those found so far have been summarized by Surlyk et al. (1973).

\section{Conclusions}

Fig. 2 shows how far we have come since those first intriguing collections brought back by Rosenkrantz and Harris were described by Spath in 1932. His Cranocephalites, Arctocephalites, Arcticoceras and Seymourites Beds included what he tentatively identified as seven ammonite faunal horizons (1932, p. 138). They correspond roughly to faunas $5,7,9,15$ and 23 . Among the forms described by him we can now additionally recognize representatives of faunas $1,4,6,12,13,18$, 21 and 22: a total of 13 out of the 37 Middle Jurassic faunas known from Jameson Land today.

The greatest interest attaches to faunas 1-30, almost all of which, because of faunal provincialism, can still not be closely correlated with their European equivalents. Faunas 1-23 are definitely pre-Callovian and span what has usually been called the Boreal Bathonian, for which they have become the standard. As discussed previously, there are in fact grounds for believing that the Borealis Zone at the base could well correspond to a level still somewhere as low as the late Lower Bajocian Humphriesianum Zone of Europe. The finest subdivisions indicated at the left of the Submediterranean Bajocian/Bathonian in fig. 2 correspond to the best faunal resolution now available for that part of the column in Europe, the product of a century and a half's intensive study. Whatever their precise correlations might be, the 23 horizons of Greenland can therefore be equivalent at most to the 32 horizons of the Humphriesianum-Discus interval in Europe. These figures need of course not be identical even ideally, for there are no reasons whatever for believing that the rates of morphological evolution of all ammonite shells were so similar and constant that the time-spacings of ammonite horizons are everywhere the same. Nevertheless, the figures are sufficiently similar to give some credence to the belief that the ammonite faunal record over this range is not much less complete in Greenland than it is in Europe. In contrast, higher in the Callovian (faunas 33-39), direct correlation with the well-known European standard is again possible and shows that the record in Greenland is here highly incomplete. This conclusion was however already quite clear from the field evidence itself. Ammonites in this part of the succession are sparse and stratigraphically widely-spaced by any standards.

Finally, what fig. 2 does not reveal is that the results it presents depend entirely on three coincidental strokes of luck. The first is that in the whole of the Arctic Boreal Province, there were in fact areas at all to which the ammonites chose during Boreal Bathonian times to return again and again to die and to leave us a succession of their shells as guide-fossils. How many of such areas there may ever have been we do not know. But they cannot have been many, for the majority with Boreal Bathonian sediments known to us to-day yield very few ammonites: even less, successions of them. Traill $\varnothing$, for instance, immediately north of Jameson Land, is for purposes of detailed Jurassic ammonite biostratigraphy quite useless. The second stroke of luck is that at least one of these favoured areas should have been preserved from loss by erosion. Not much of the Middle Jurassic that once undoubtedly covered the East Greenland shelf has survived. And thirdly, we are lucky also to have one of the preserved, favoured areas so well exposed at outcrop as in Jameson Land. The sediments could have been covered by ice, as they still are on Olympen; or in moraines and other superficial deposits, as they are in parts of central Jameson Land; or in Tertiary basalts as, if preserved at all, they must be everywhere south of Scoresby Sund. 
In the Upper Jurassic, the same three factors have converged even more acutely in the tiny surviving outlier at Kap Leslie in Milne Land.

All these points are obvious and barely worth making. They do however raise some questions that are important in more general contexts. How much would we have known about Arctic Jurassic biostratigraphy, biogeography and chronology had the successions of Jameson and Milne Lands no longer existed or never been discovered? The geological record is notoriously incomplete, but at what scale? The discoveries in Greenland have perchance filled one or two gaps and, perhaps more importantly, shown how large such gaps can still be. How many other such gaps remain to be filled, and where? Are there some that will never be filled because the evidence has been permanently lost, for example by subduction along the whole of the northern rim of the Tethys and Pacific between the Pamirs and Alaska? The moral of Greenland is that, even after a century and a half of world-wide study of a System as intensively explored as the Jurassic has been, it would be rash to assume that our knowledge must necessarily now be close to complete.

Acknowledgments. The results described here have depended heavily on the help of many friends and colleagues. I am indebted to the late Lauge Koch and to the Geological Survey of Greenland for allowing me to take part in their expeditions; to Desmond $T$. Donovan for first introducing me to the ways of such enterprises in 1957; and to H. Nünlist, J.-P. Parel, D. Steiner (1957), R. L. Makin and J. C. Wigglesworth (1958) for helping in the field. Some important collections made and sections recorded in 1964 by D. Brown, R. Marris and R. C. Whatley during a small expedition to Jameson Land in 1964, supported in part by a grant from the Royal Society, have been incorporated in the material on which the present account is based, as have some other small collections made before the war during others of Koch's expeditions, by Aldinger (1933), Rosenkrantz and Bütler (1934) and Stauber (1938), and recovered from the British Museum (Natural History) where they had been lying waiting to be described by Spath. Further collections made during GGU's survey of the Hurry Inlet and Carlsberg Fjord sheets (1968-71) by Ulla Asgaard, R. G. Bromley, E. Hăkansson and F. Surlyk as well as by Tove Birkelund and C. Heinberg (1974), are also included. All these collections are, or will be, kept in the Geologisk Museum, Copenhagen.

My deepest expressions of debt must however go to Tove Birkelund, for her companionship during three memorable field seasons, for the stimulus of innumerable discussions on all aspects of geology from which I learned so much, and for her hospitality during many visits to Copenhagen. The impressive range of results obtained in East Greenland after the resumption of geological mapping by GGU in 1968 owes a very great deal to her leadership in taking charge of the "soft-rock" side of the exploration, from initial planning through to the publication of results. Her contributions to the more detailed work described here were also energetic and sustained; and the memory that lingers is of a long day in the middle of Jameson Land, four hours' trudge away with $30 \mathrm{~kg}$ of rocks on the back, from two tiny tents that counted as home, all alone where no man had ever stood before, in total stillness, surrounded only by distant views of bare slopes and glaciers bathed in the dusky golden glow of the midnight sun.

\section{Dansk sammendrag}

Ammonitforekomsterne $i$ det mellem jurassiske interval $i$ det centrale Østgrønland er de mest komplette og velstuderede fra det arktiske område og er blevet en standard for hele den boreale faunaprovins. Der er 37 forskellige selskaber, som karakteriserer en tidsfølge af aflejringer. Denne tidsfølge er opnảet gennem studier af mere end 80 forskellige fossilførende sedimentære sekvenser på Jameson Land mellem Scoresby Sund og Kong Oscars Fjord. Ammonitforekomsterne udgør rygraden $i$ den regionale stratigrafi.

Ammonitselskaberne gennemgåes med henvisning til allerede publiserede beskrivelser. Faunaerne nr. 1-23 er af pracallovien alder og har ingen repræsentanter fælles med deres formodede samtidige $i$ det europæiske område. De kan derfor endnu ikke korreleres med den europxiske ammonit standardzonering. De fleste af dem mà nok tilhøre bathonien tiden, selv om de tidligste nok tilhører bajocien. Bathonien-callovien grænsen ligger sandsynligvis inden for fauna 24-26, som ligner den europæiske fauna i keppleri zonen i den nederste del af callovien. Faunaerne 27-35 omfatter resten af nedre callovien. mens faunaerne $36 \mathrm{og} 37 \mathrm{er}$ den eneste indikation på mellem og $\emptyset \mathrm{vre}$ callovien. Ammonitterne fra Jameson Land, der tidligere er beskrevet af Spath (1932), er i dette arbejde revideret og henført til deres rette niveauer. Blandt 11 nye arter bliver kun en beskrevet nemlig Kepplerites vardekloeftensis. Den er af sen bathonien alder.

\section{References}

Aldinger, H. 1935: Geologische Beobachtungen im Oberen Jura des Scoresbysundes (Ostgrönland). Meddr Grønland 99 (1), $128 \mathrm{pp}$.

Arkell, W. J. 1939: The ammonite succession at the Woodham Brick Company's pit, Akeman Street Station, Buckinghamshire, and its bearing on the classification of the Oxford Clay. Quart. Jl geol. Soc. London 95, 135-222.

Arkell, W. J. 1956: Jurassic Geology of the World. Oliver \& Boyd, Edinburgh \& London, xiv + 806 pp.

Birkelund, T., Callomon, J. H. \& Fürsich, F. T. 1984: The stratigraphy of the Upper Jurassic and Lower Cretaceous sediments of Milne Land, central East Greenland. Bull. Grønlands geol. Unders. 147, $56 \mathrm{pp}$.

Birkelund, T., Håkansson, E. \& Surlyk, F. 1971: New finds of Bathonian, Callovian and Oxfordian ammonites in northern Jameson Land, East Greenland. Bull. Geol. Soc. Denmark 20, 240-59.

Birkelund, T. \& Perch-Nielsen, K. 1976: Late PalaeozoicMesozoic evolution of central East Greenland. In Esher, A. \& Watts, W. S. (eds.): Geology of Greenland, Copenhagen, Grønlands Geol. Unders., 304-39.

Blake, J. F. 1905-7: A monograph of the fauna of the Cornbrash. Monogr. Palaeontogr. Soc. London, $106 \mathrm{pp}$.

Bodylevsky, V. I. 1960: Callovian ammonites from northern Siberia (Kelloveyskie ammonity severnoy Sibirj; in Russian). Zap. Leningradskogo Gornogo Institut 37 (2), 49-82.

Buckman, S. S. 1919-25: Type Ammonites, vols. 3-5, London, Wheldon \& Wesley, pl. 131-576, 64 pp.' (1921), 67 pp. (1923), 88 pp. (1925). 
Callomon, J. H. 1959: The ammonite Zones of the Middle Jurassic beds of East Greenland. Geol. Mag. 96, 505-13

Callomon, J. H. 1972: Jurảssic System. In Callomon, J. H. Donovan, D. T. \& Trümpy, R.: An annotated map of the Permian and Mesozoic formations of East Greenland. Meddr Grønland 168 (3), 15-21.

Callomon, J. H. 1976: Jurassic ammonites from the northern North Sea. Norsk geol. Tidsskr. 55, 373-86.

Callomon, J. H. 1979: Marine Boreal Bathonian fossils from the northern North Sea and their palaeogeographical significance. Proc. Geol. Assoc. 90, 163-9.

Callomon, J. H. 1984: A review of the biostratigraphy of the post-Lower Bajocian Jurassic ammonites of western and northern North America. In Wéstermann, G. E. G. (ed.): Jurassic-Cretaceous biochronology and paleogeography of North America, Geol. Assoc. Canada Spec. Paper 47, 143-74.

Callomon, J. H. 1985a: Biostratigraphy, chronostratigraphy and all that - again! In Michelsen, O. \& Zeiss, A. (eds.): International Symposium on Jurassic Stratigraphy, Erlangen 1984, Geol. Survey Denmark, Copenhagen, 3, 611-24.

Callomon, J. H. 1985b: The evolution of the Jurassic ammonite family Cardioceratidae. In Cope, J. C. W. \& Skelton, P. R. (eds.): Evolutionary case histories from the fossil record, Spec. Papers Palaeont. 33, 49-90.

Callomon, J. H. \& Birkelund, T. 1980: The Jurassic transgression and the mid-late Jurassic succession in Milne Land, central East Greenland: Geol. Mag. 117, 211-26:

Callomon, J. H. \& Birkelund, T. 1982: The ammonite Zones of the Boreal Volgian (Upper Jurassic) in East Greenland. In Embry, A. F. \& Balkwill, H. R. (eds.); Arctic Geology and Geophysics, Canad. Soc. Petrol. Geol., Mem. 8, 349-69.

Callomon, J. H, \& Birkelund, T. 1985: Appendix: description of three new species. In Callomon J. H. 1985b, 78-86.

Callomon, J. H., Dietl, G. \& Niederhöfer, H.-J. 1989: The ammonite faunal horizons at the Bathonian-Callovian boundary in the Swabian Jurassic and their correlation with those of western France and England. Stuttgarter Beitr. Naturk. 148 (B), 13 p.

Callomon, J. H., Diet1, G. \& Page, K. N. 1989: On the ammonite faunal horizons of the Lower Callovian Stage in Europe. In Rocha, R. B. \& Zeiss, A. (eds.): 2nd Internat. Symposium on Jurassic Stratigraphy, Lisbon 1987, Universidada Nova de Lisboa, Lisbon, 1, 359-76.

Callomon, J. H. \& Wright, J. K. 1989: Cardioceratid and Kosmoceratid ammonites from the Callovian of Yorkshire. Palaeontology 32, 799-836.

Dietl, G. \& Callomon, J. H. 1988: On the Orbis Oolite (Orbis Zone, Upper Bathonian, Middle Jurassic) of Sengenthal Opf., Franconian Alb, and its significance for the correlation and subdivision of the Orbis Zone. Stuttgarter Beitr. Naturk. 142 (B), 31 p.

Donovan, D. T. 1953: The Jurassic and Cretaceous stratigraphy and palaeontology of Traill $\varnothing$, East Greenland. Meddr Grønland 111 (4), $150 \mathrm{p}$.

Donovan, D. T. 1957: The Jurassic and Cretaceous Systems in East Greenland. Meddr Gronland 155 (4), 214 p.

Douglas, J. A. \& Arkell, W. J. 1928: The stratigraphical distribution of the Cornbrash. I. The south-western area. Quart. Jl geol. Soc. London 84, 117-78.

Douvillé, R. 1911: Ammonites Tchefkini d'Orbigny, 1845. Palaeontologia Universalis, 214. International Geological Congress.

Ershova E. S. \& Meledina S. V. 1968: Late Bathonian Oppeliidae of Northern Siberia (Pozdnebatskie oppelidy Severa Sibiri; in Russian). Trudy Inst. Geol. Geofiz. Akad Nauk SSSR, Sib. otdel., 38, 42-50.

Frebold, H. 1958: Fauna, age and correlation of the Jurassic rocks of Prince Patrick Island. Bull. Geol. Surv, Canada 41, 69 pp.
Frebold, H. 1961: The Jurassic faunas of the Canadian Arctic

Middle and Upper Jurassic ammonites: Bult: Geol: Surv. Canada 74, 43 pp.

Frebold, H: 1964: The Jurassic faunas of the Canadian Arctic. Cadoceratinae. Bull. Geol. Surv. Canada 119, 27 pp.

Heinberg, C. \& Birkelund, T. 1984: Trace-fossil assemblages and basin evolution of the Vardekløft Formation (Middle Jurassic, central East Greenland). J. Paleont. 58, 362-97.

Imlay, R. W. 1953: Callovian (Jurassic) ammonites from the United States and Alaska. Pt. 2. Alaska Peninsula and Cook Inlet regions. Prof. Paper U.S. Geol. Surv. 249-B, 41-108.

Imlay, R. W. 1975: Stratigraphic distribution and zonations of Jurassic (Callovian) ammonites in southern Alaska. Prof. Paper U.S. Geol. Surv. 836, 28 pp.

Keyserling, A. v. 1846: Wissenschaftliche Beobachtungen auf einer Reise in das Petschoraland im Jahre 1843. Carl Kray, St. Petersburg, 465 pp.

Krymholts, G. Ya., Mesezhnikov, M. S. \& Westermann, G. E. G. 1988: The Jurassic ammonites Zones of the Soviet Union. Geol. Soc. Amer. Spec. Paper 223, viii + 116 pp.

Lominadze, T. A. \& Sakharov, A. S. 1985: The Kosmoceratidae of the Caucasus (Kosmotseratidy Kavkaza; in Russian). Inst. Paleobiology, Akad. Nauk Gruzinskoi SSR, Tbilisi, 62 pp.

Luppov, N. P. \& Drushchits, V. V: (eds.) 1958: Mollusca Cephalopoda II. Ammonoidea (Ceratitina, Ammonitina). Endocochlia. Osnovy Paleontologii 15. 358 pp. National Scientific-Technical Publisher on Geology and Oil-conservation, Moscow.

Madsen, V. 1904: On Jurassic fossils from East-Greenland. Meddr Grønland 29, 157-211.

Meledina, S. V. 1967: A new genus of Middle Jurassic Arctic ammonites (Novyi rod sredneyurskikh arkticheskikh ammonitov; in Russian). In Saks, V. N. (ed.): Problems of paleontologic substantiation of detailed Mesozoic stratigraphy of Siberia and the Far East of the USSR. Nauka, Leningrad, 103-9.

Meledina, S. V. 1971: Ammonites and zonal stratigraphy of the Bajocian-Bathonian of Siberia (Ammonity i zonal'naya stratigrafiya Baiosa-Bata Sibiri; in Russian): Trudy Inst. Geol. Geofiz. Akad. Nauk, Sib. otdel., 153, 152 pp.

Meledina, S. V. 1987: Ammonites and zonal stratigraphy of the Callovian of the subboreal regions of the USSR (Ammonity i zonal'naya stratigrafiya Kelloveya subboreal'nikh rayonov SSSR; in Russian). Trudy Inst. Geol. Geofiz. Akad. Nauk, Sib. otdel., 691, 184 pp.

Nikitin, S. N. 1881: Die Juraablagerungen zwischen Rybinsk, Mologa und Myschkin an der oberen Wolga. Mém. Acad. imp. Sci. St. Petersbourg [vii] 28 (5), 98 pp.

Nikitin, S. N. 1885: Der Jura der Umgebung von Elatma. 2. Lief. Mém. Soc. imp. Nat. Moscou, n.s. 15, 41-66.

Newton, E. T. 1897: in - \& Teall, J. H. H., Notes on a collection of rocks and fossils from Franz Josef Land, made by the Jackson-Harmsworth Expedition during 1894-1896. Quart. Il geol. Soc. London 53, 477-519.

Orbigny A. d' 1845: Terrain secondaire. Système Jurassique (Etage Oxfordien). Mollusques. In Murchison, R. I., de Verneuil, E. \& Keyserling, A., Geologie de la Russie d'Europe et des montagnes de l'Oural, II, $3^{c}$ partie, Paléontologie, 419-88. John Murray, London \& Bertrand, Paris.

Page, K. N. 1989: A stratigraphical revision for the English Lower Callovian. Proc. Geol. Assoc. 100, 363-82.

Parkinson, M. M. L. \& Whittard, W. F. 1931: The geological work of the Cambridge Expedition to East Greenland in 1929. Quart. Jl geol. Soc. London 87, 650-74.

Pompeckj, J. F. 1900: The Jurassic fauna of Cape Flora, Franz Josef Land. In Nansen, F. (ed.): The Norwegian North Polar Expedition 1893-1896, Scientific results. Vol. I, 33 148. Longmans, Green \& Co., London etc. 
Poulton, T. P. 1982: Paleogeographic and tectonic implications of the Lower and Middle Jurassic facies patterns in northern Yukon Territory and adjacent Northwest Territories. In Embry, A. F. \& Balkwill, H. R. (eds.): Arctic Geology and Geophysics, Canad. Soc. Petrol. Geol., Mem. 8, 13-27.

Poulton, T. P. 1987: Zonation and correlation of Middle Boreal Bathonian to Lower Callovian (Jurassic) ammonites, Salmon Cache Canyon, Porcupine River, northern Yukon. Geol. Surv. Canada Bull. 358, vii +155 pp.

Poulton, T. P. \& Callomon, J. H. 1976: Major features of the Lower and Middle Jurassic stratigraphy of northern $\mathrm{Ri}$ chardson Mountains, northeastern Yukon Territory and northwestern District of Mackenzie. Geol. Surv. Canada Paper 76-1B, 345-52.

Poulton, T. P., Leskiw, K. \& Audretsch, A. 1982: Stratigraphy and microfossils of the Jurassic Bug Creek Group of northern Richardson Mountains, northern Yukon and adjacent Northwest Territories. Geol. Surv. Canada Bull. 325, x + $137 \mathrm{pp}$.

Ravn, J. P. J 1911: On Jurassic and Cretaceous fossils from northeast Greenland. Meddr Grønland 45 (10), 433-500.

Rawson, P. F. 1982: New Arctocephalitinae (Ammonoidea) from the Middle Jurassic of Kong Karls Land, Svalbard. Geol. Mag. 119, 95-100.

Rosenkrantz, A. 1929: Prelimnary account of the geology of Scoresby Sund district. In Koch, L.: The geology of East Greenland. Meddr Gronland 73, 135-54.

Salfeld, H. \& Frebold, H. 1924: Jura- und Kreidefossilien von Nowaya Zemlya. Rept Sci. Res. Norwegian Exped. Novaya Zemlya 23, 12 pp. Videnskapsselskapet i Kristiania, Oslo.

Saks, V. N. (ed.) 1976: Stratigraphy of the Jurassic System of the north of the USSR (Stratigrafiya Yurskoi Sistemy Severa SSSR; in Russian). Nauka, Moscow, 436 pp.

Sazonov, N. T. 1957: The Jurassic deposits in the central region of the Russian Platform (Yurskie otlozheniya tsentral'nikh oblastei Russkoy Platformy; in Russian). VNIGNI, Leningrad, $155 \mathrm{pp}$.

Sokolov, D. N. 1912: Zur Ammonitenfauna des Petschoraschen Jura. Mém. Comité géol. St. Petersbourg, N. S. 76 , 1-49 (Russian text), 50-65 (German summary).

Sokolov, D. N. 1913: Sur les fossiles des blocs erratiques de Novaia Zemlia. Trav. Mus. géol. Pierre le Grand Akad. imp. Sci. St. Petersbourg 7, 59-92.

Sokolov, D. N. \& Bodylevsky, W. 1931: Jura- und Kreidefaunen von Spitzbergen. Skr. Svalbard og Ishavet 35, $151 \mathrm{pp}$.

Spath, L. F. 1932: The invertebrate faunas of the BathonianCallovian deposits of Jameson Land (East Greenland). Meddr Grønland 87 (7), 158 pp.

Spath, L. F. 1939: The ammonite Zones of the Upper Oxford Clay of Warboys, Huntingdonshire. Bull. Geol. Surv. Gt Britain 1, 82-98.

Surlyk, F., Callomon, J. H., Bromley, R. G. \& Birkelund, T. 1973: Stratigraphy of the Jurassic-Lower Cretaceous sediments of Jameson Land and Scoresby Land, East Greenland. Bull. Grønlands geol. Unders. 105 (also Meddr Grønland 193 (5)), $76 \mathrm{pp}$.

Voronets, N. S. 1957: First discovery of Morrisiceras and Xenocephalites in Northern Siberia (Pervye nakhodki ... na Severe Sibiri; in Russian). Sbornik Statei Paleont. Biostratigr. 7, 20-23.

Voronets, N. S. 1962: Stratigraphy and cephalopod molluscs from Jurassic and Lower Cretaceous deposits of the LenaAnabar region (Stratigrafiya i golovonogie molliuski yurskikh i nizhnemelovikh otlozhenii Leno-Anabarskogo rayona; in Russian). Trudy, Nauch.-issled. Inst. Geol. Arktiki (NIIGA) 110, 237 pp.

Whitfield, R. P. 1907: Notes on some Jurassic fossils from Franz Josef Land, brought by a member of the Ziegler Exploring Expedition. Bull. Amer. Mus. Nat. Hist. 22, 131-4. 


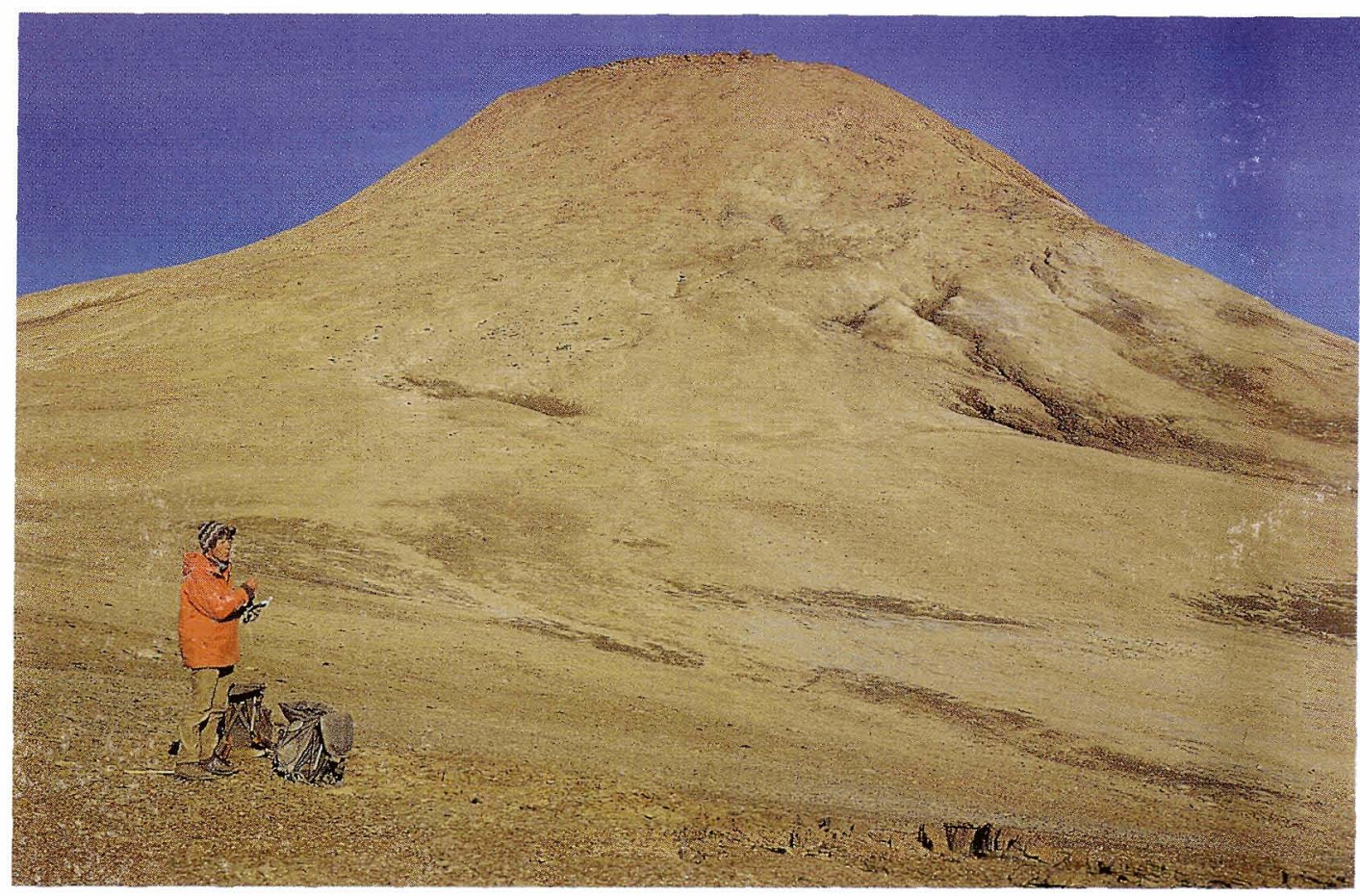

70-30. Kosmoceras Bjerg, northern Jameson Land: sandstones of the upper Vardekløft Formation capped by Olympen Formation, representing almost the whole of Callovian and the lowermost Oxfordian Stages. In the foreground, a sandstone in the same facies and of the same age as the classical Kellaways Rock of Wiltshire in England, so named by William Smith, with abundant ammonites of the Calloviense Zone, including Sigaloceras calloviense (J. Sowerby).

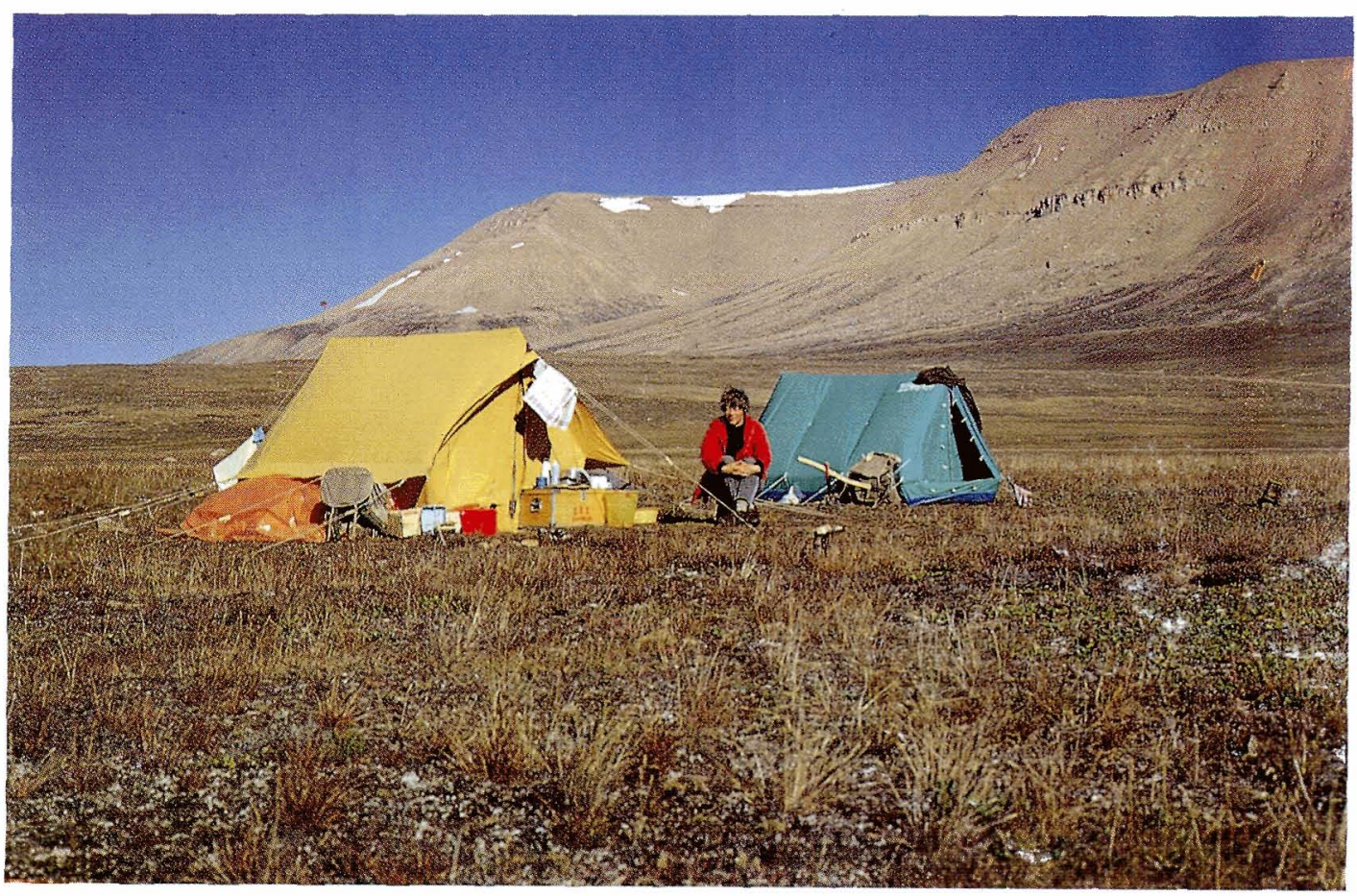

70-39. Pingel Dal, northern Jameson Land: Middle Jurassic sandstones of the Pelion Member of the Vardekløft Formation, of early boreal Bathonian age. 


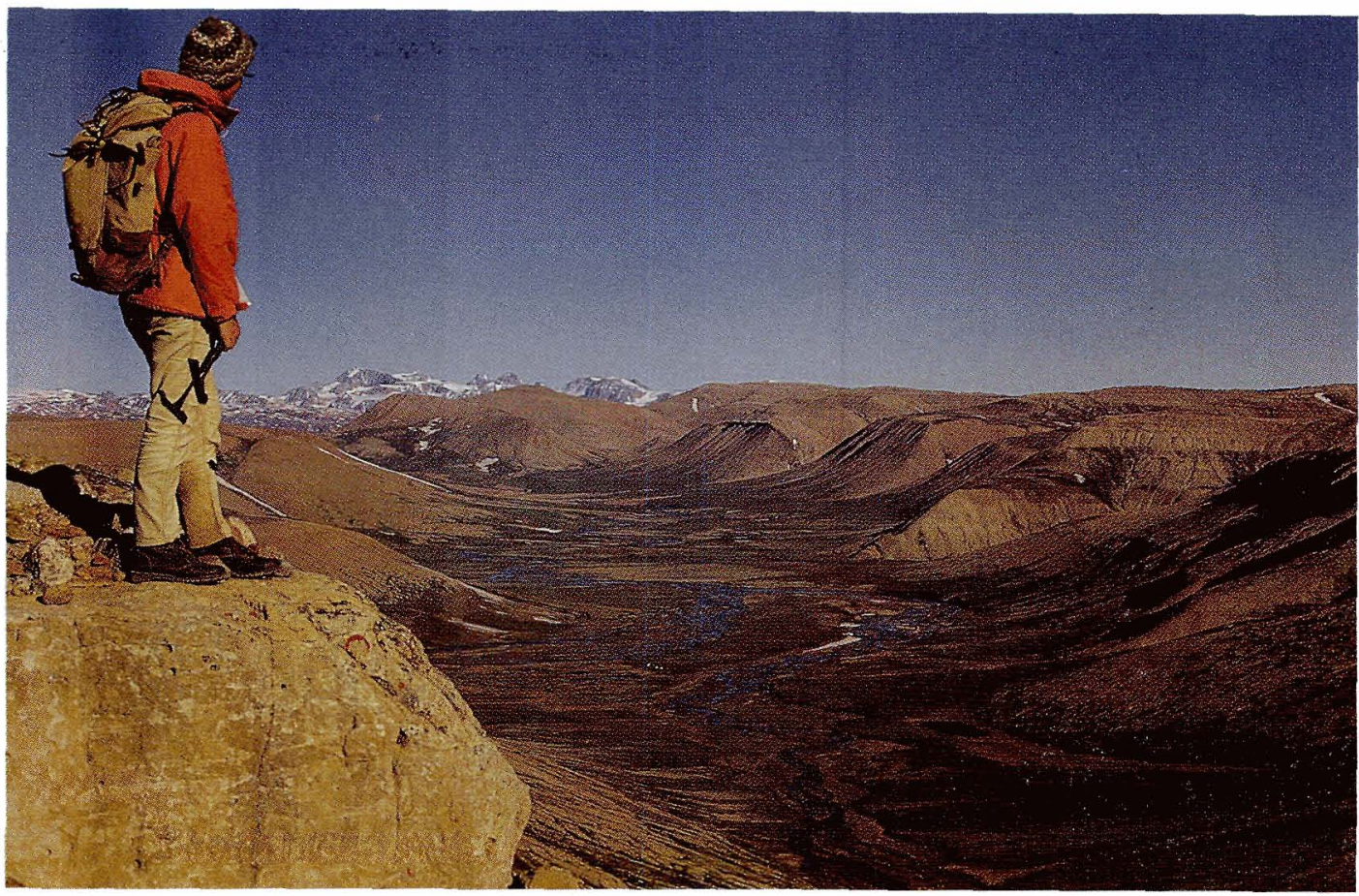

71-2. Ugleelv, southern Jameson Land, looking east towards the head of Hurry Inlet with ice-capped peaks of Liverpool Land in the far distance; Katedralen lies to the right. Pelion Member of the Vardekløft Formation (foreground) on Liassic Neill Klinter Formation (hills in the middle distance).

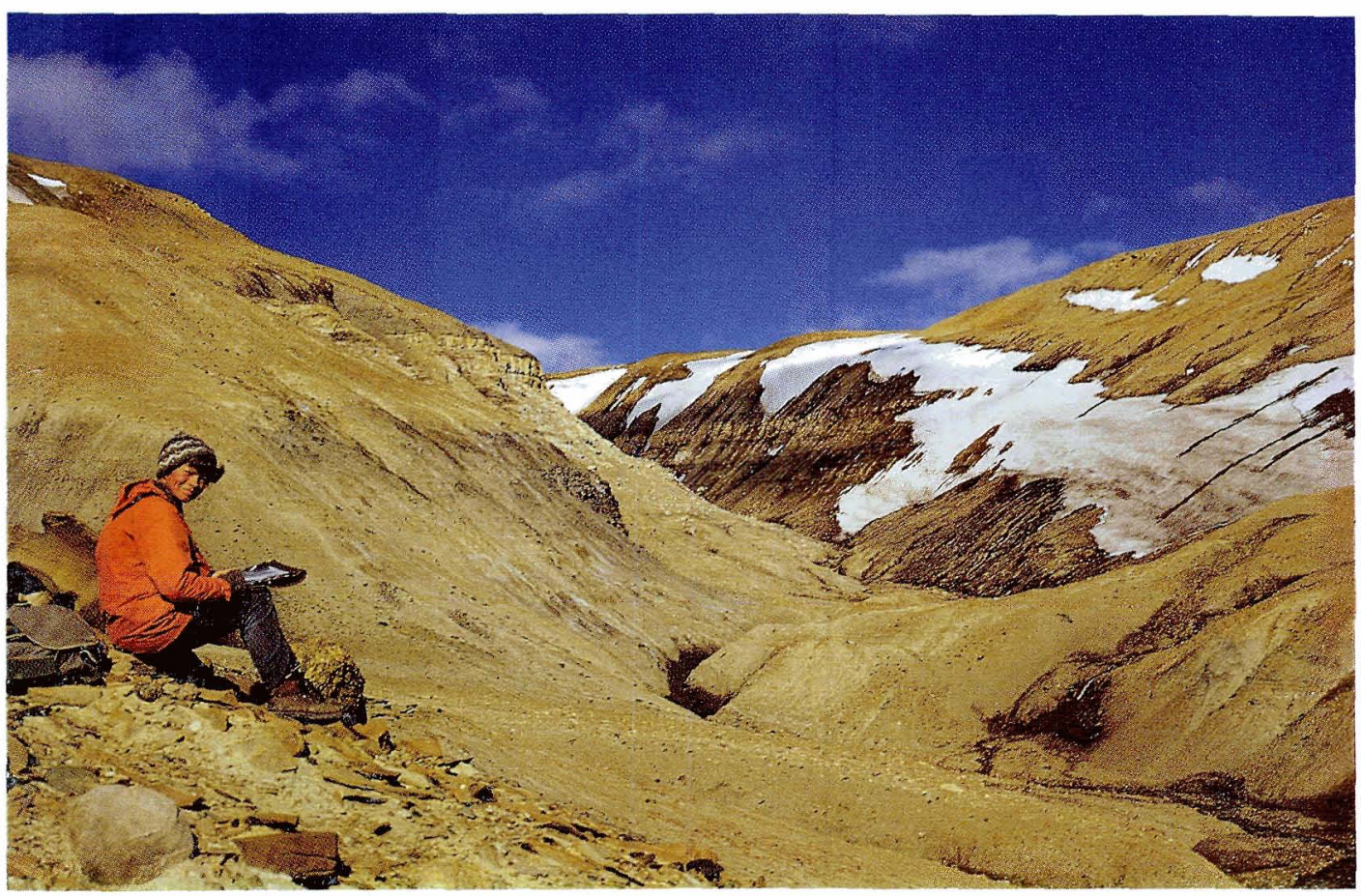

70-25. Jameson Land, upper Olympen Elv, looking north. In the foreground, Fossilbjerget Member of the Vardekløft Formation: dark, silty shales with layers of concretions of Lower Callovian age, grading upwards (middle distance) into sandstones of the Olympen Formation, of Lawer-Middle Oxfordian age. 


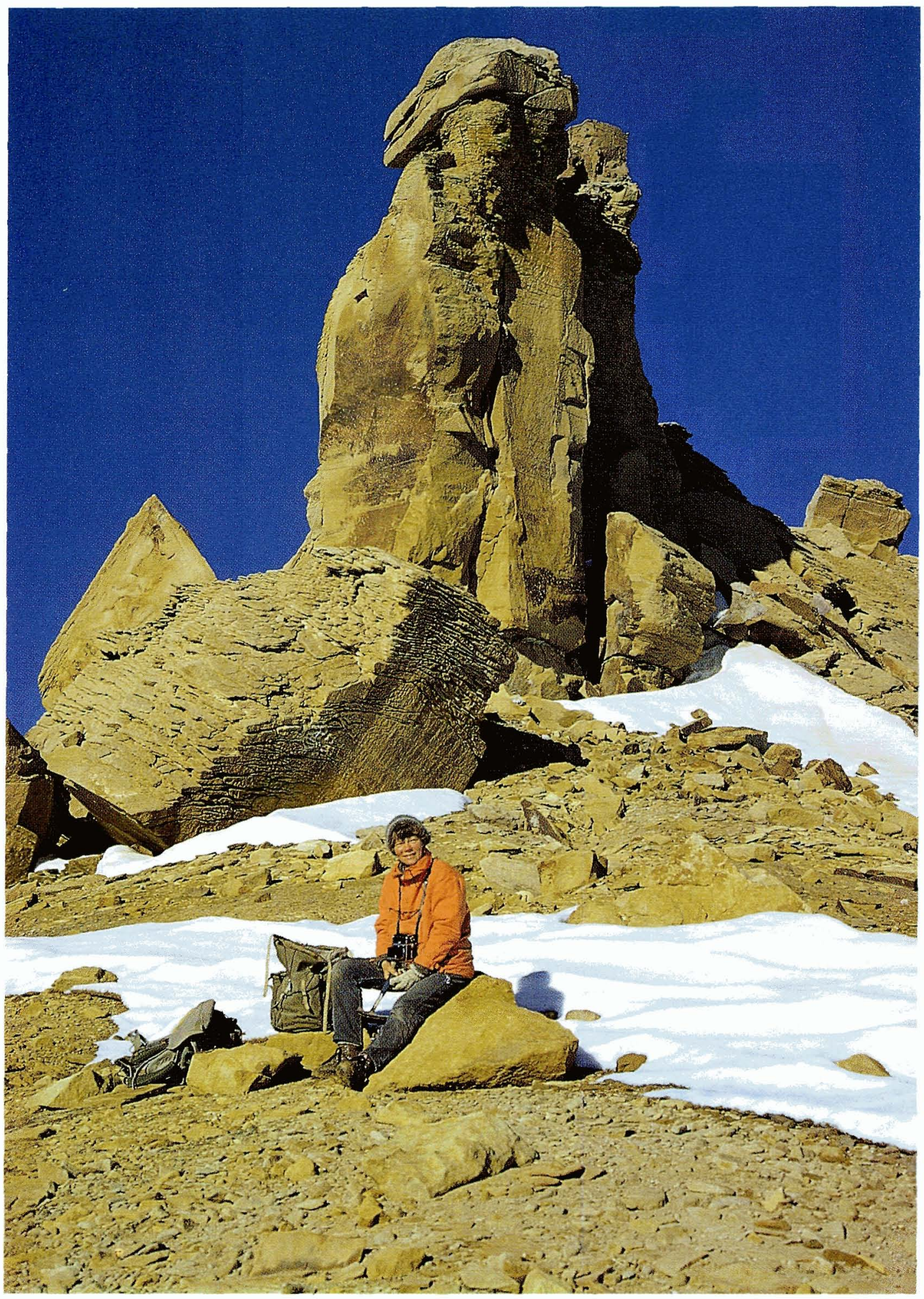

70-52. Parnas, northern Jameson Land, looking north: giant foreset sandstone buttress on the southern ridge, in the lower Olympen Formation, of Oxfordian age. 